\title{
EFEITOS DE FONTES E NIIVEIS DE FIBRA ÍNTEGRA, EM DIETAS CONTENDO BAGAÇO DE CANA-DE-AÇÚCAR TRATADO SOB PRESSÃO E VAPOR, SOBRE A DIGESTIBILIDADE, DESEMPENHO E COMPORTAMENTO INGESTIVO DE BOVINOS DE CORTE
}

\author{
MÁRIO MÁRCIO ARAKAKI RABELO
}

\begin{abstract}
Dissertação apresentada à Escola Superior de Agricultura "Luiz de Queiroz", Universidade de São Paulo, para obtenção do título de Mestre em Agronomia, Área de Concentração: Ciência Animal e Pastagens.
\end{abstract}

PIRACICABA

Estado de São Paulo - Brasil

Janeiro - 2002 


\title{
EFEITOS DE FONTES E NIIVEIS DE FIBRA ÍNTEGRA, EM DIETAS CONTENDO BAGAÇO DE CANA-DE-AÇÚCAR TRATADO SOB PRESSÃO E VAPOR, SOBRE A DIGESTIBILIDADE, DESEMPENHO E COMPORTAMENTO INGESTIVO DE BOVINOS DE CORTE
}

\author{
MÁRIO MÁRCIO ARAKAKI RABELO \\ Médico Veterinário
}

Orientador: Prof. Dr. ALEXANDRE VAZ PIRES

Dissertação apresentada à Escola Superior de Agricultura "Luiz de Queiroz", Universidade de São Paulo, para obtenção do título de Mestre em Agronomia, Área de Concentração: Ciência Animal e Pastagens.

PIRACICABA

Estado de São Paulo - Brasil

Janeiro- 2002 
Dados Internacionais de Catalogação na Publicação (CIP) DIVISÃO DE BIBLIOTECA E DOCUMENTAÇÃO - ESALQ/USP

\section{Rabelo, Mário Márcio Arakaki}

Efeitos de fontes e níveis de fibra íntegra, em dietas contendo bagaço de cana- de- açúcar tratado sob pressão e vapor, sobre a digestibilidade, desempenho e comportamento ingestivo de bovinos de corte / Mário Márcio Arakaki Rabelo. - - Piracicaba, 2002.

$61 \mathrm{p}$.

Dissertação (mestrado) - - Escola Superior de Agricultura Luiz de Queiroz, 2002.

Bibliografia.

1. Bagaço de cana- de- açúcar 2. Bovinocultura de corte 3. Dieta animal 4. Digestibilidade I. Título

CDD 636.213

"Permitida a cópia total ou parcial deste documento, desde que citada a fonte - $O$ autor" 
A Deus que presente em todos os lugares se mostra de forma humilde e despercebida, mas que na sua maior expressão: a vida ; sentimos sua presença.

\section{OFEREÇO}

Ao meu pai Oscar Pedro,

A minha mãe Elza,

A minha irmã Márcia.

DEDICO 


\section{AGRADECIMENTOS}

Mesmo que passe o tempo e as distâncias sejam insuperáveis, jamais deixarei de lembrar aqueles que me ensinaram, auxiliaram, incentivaram e acreditaram na realização deste trabalho, por isso: Muito Obrigado,

Ao Prof. Dr. Alexandre Vaz Pires pela confiança, amizade, pelos ensinamentos e pela orientação imprescindível para a realização deste trabalho.

A todos os professores do Departamento de Produção Animal, em especial à Prof. Dr. Ivanete Susin, ao Prof. Dr. Luiz Gustavo Nussio e ao Prof. Dr. Wilson Mattos.

Aos amigos e colegas de curso, Simone, Rodrigo, Juliano, Reinaldo, Adriana, Rafael, Décio, Hugo e Márcia Helena e em especial ao amigo e colega Vicente pelo auxílio na condução do experimento de digestibilidade.

À Escola Superior de Agricultura "Luiz de Queiroz" (ESALQ/USP) e ao Departamento de Produção Animal pela oportunidade de realização deste curso.

À Universidade Federal de Mato Grosso do Sul pela minha formação.

Ao Sr. Carlos César Alves pela grande colaboração nas análises bromatológicas.

Ao Sr. Silvio Rubens Rizato, Valci Rizato, Matheus e Gisele pelo apoio, incentivo e acolhida.

À Rubia Rizato pelo amor, carinho, apoio, compreensão, auxílio na condução do experimento, enfim pela força em continuar sempre em frente.

À Capes pela concessão de bolsa de estudos durante o curso.

À Usina Vale do Rosário pela doação do bagaço de cana-de-açúcar in natura e tratado sob pressão e vapor e parte dos demais constituintes das dietas usados no experimento.

A todos que de uma forma ou de outra estiveram presentes. 


\section{SUMÁRIO}

Página

LISTA DE FIGURAS........................................................................... vii

LISTA DE QUADROS .............................................................................. viii

LISTA DE TABELAS............................................................................... ix

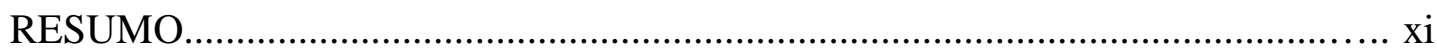

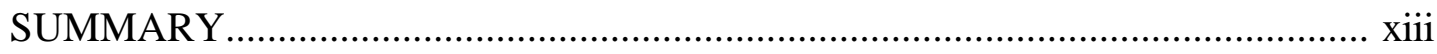

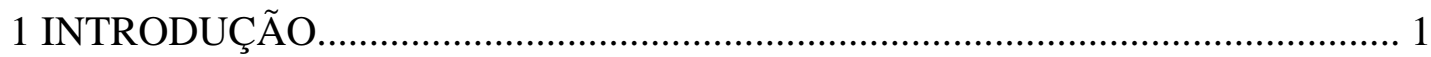

2 REVISÃO DE LITERATURA...................................................................... 3

2.1 Bagaço de cana-de-açúcar tratado sob pressão e vapor........................................ 3

2.2 Bagaço de cana-de-açúcar in natura ................................................................ 5

2.3 A fibra na nutrição de ruminantes................................................................ 8

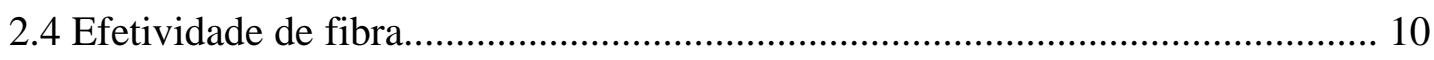

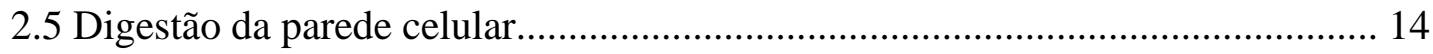

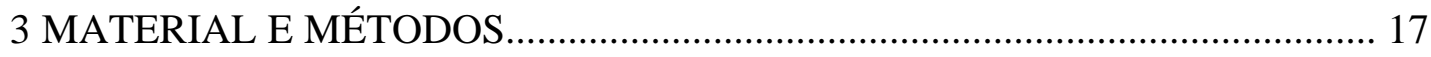

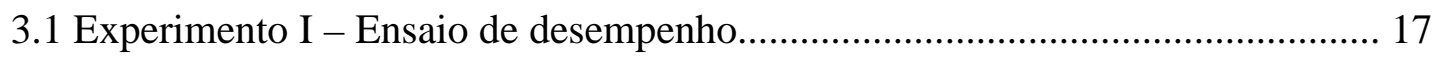

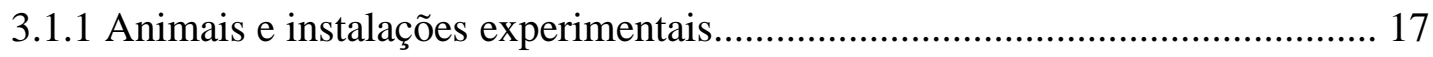

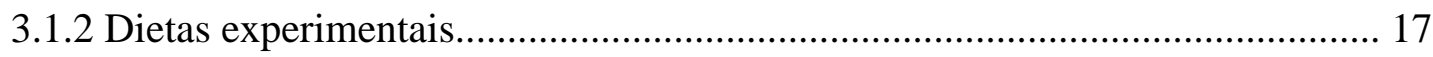

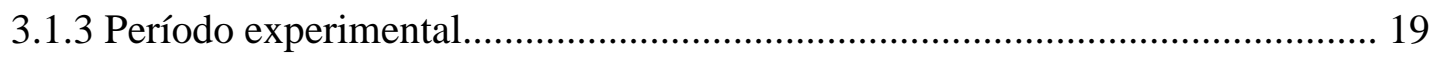

3.1.4 Coleta de dados referentes ao consumo de matéria seca................................ 19

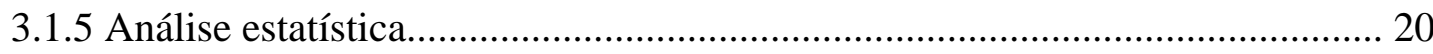

3.2 Experimento II - Ensaio de digestibilidade e avaliação de

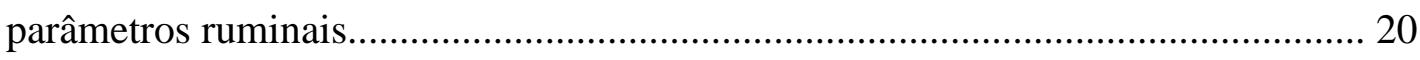

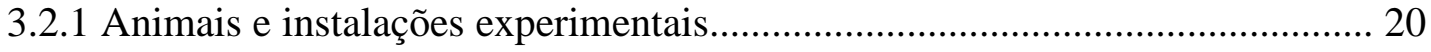

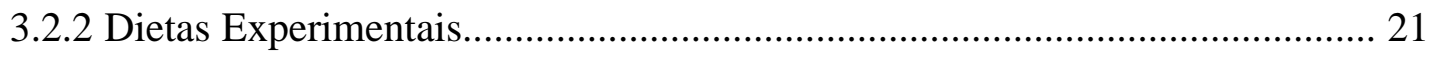

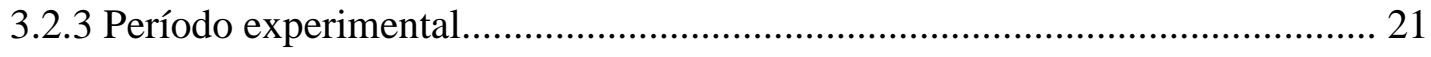

3.2.4 Coleta de dados referentes ao consumo de matéria seca................................. 21 
3.2.5 Coleta de amostras para determinação da digestibilidade

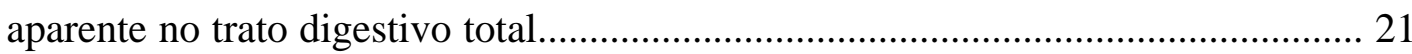

3.2.6 Coleta de amostras para determinação da digestibilidade

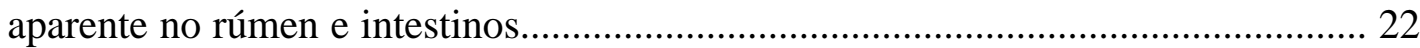

3.2.7 Análise bromatológica das dietas, sobras e fezes...................................... 23

3.2.8 Coleta de conteúdo ruminal para determinação do pH, ácidos graxos voláteis (AGV) e amônia............................................................... 24

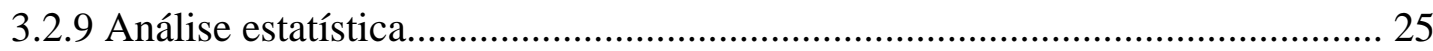

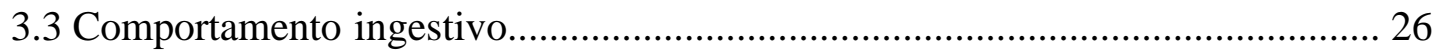

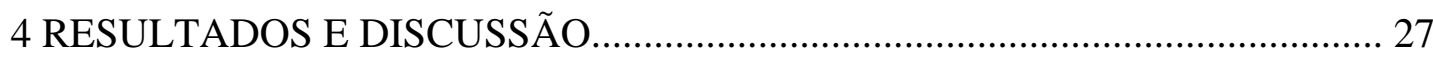

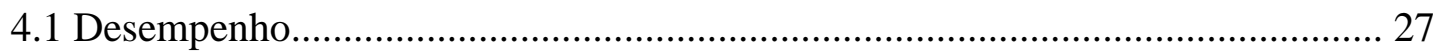

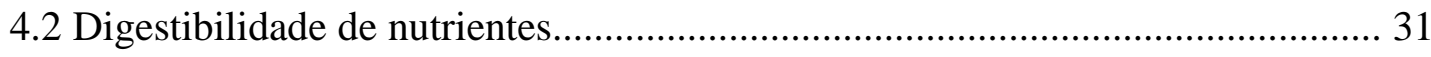

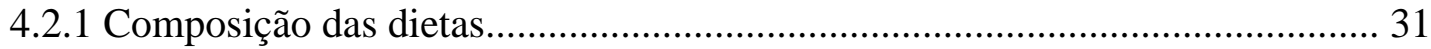

4.2.2 Efeito dos tratamentos sobre o consumo voluntário de matéria seca e digestibilidade aparente no trato digestivo total............................... 32

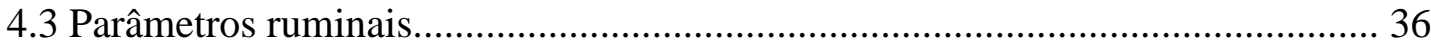

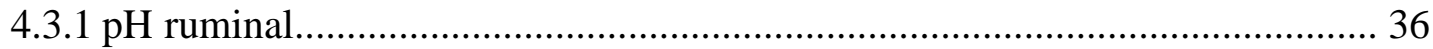

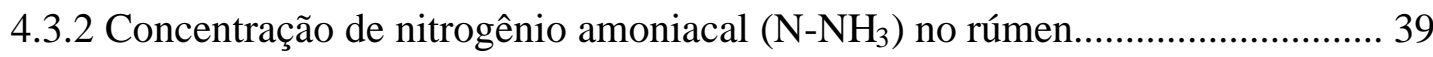

4.3.3 Concentração ruminal de ácidos graxos voláteis (AGV) ................................. 41

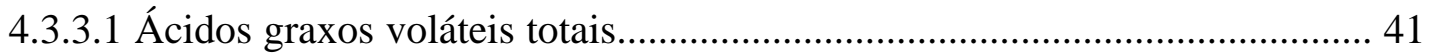

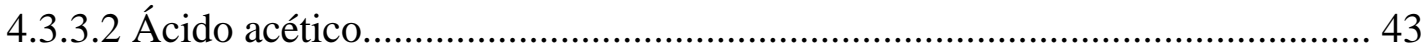

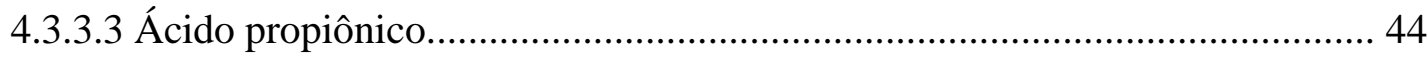

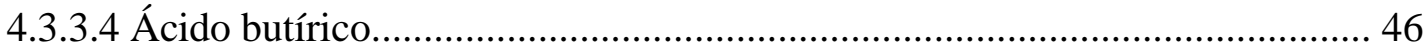

4.3.3.5 Relação acético/propiônico................................................................. 48

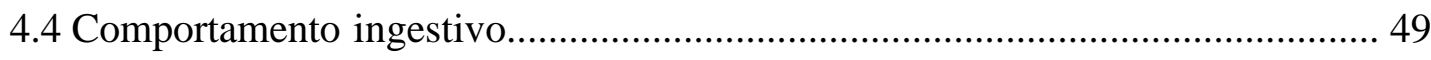

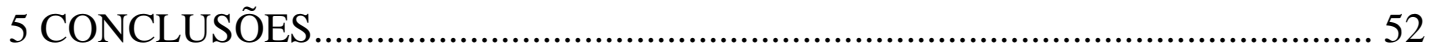

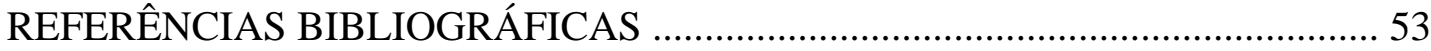




\section{LISTA DE FIGURAS}

Página

1 Efeitos dos tratamentos sobre a variação diurna do $\mathrm{pH}$

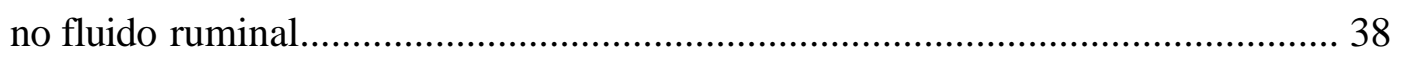

2 Efeito dos tratamentos sobre a concentração ruminal

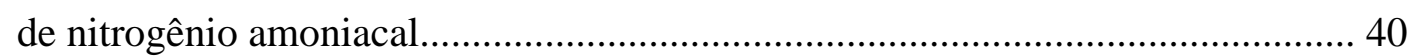

3 Efeitos dos tratamentos sobre a concentração ruminal

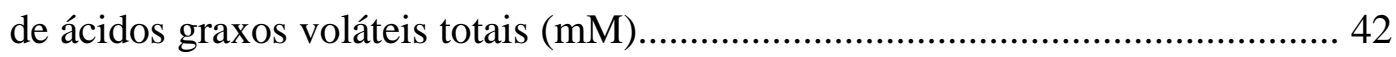

4 Efeito dos tratamentos sobre a concentração ruminal

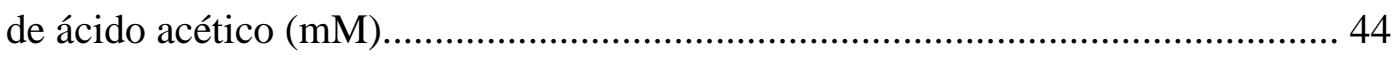

5 Efeito dos tratamentos sobre a concentração ruminal

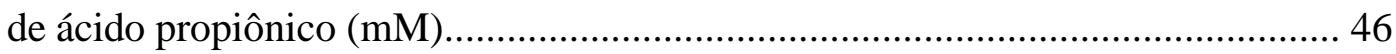

6 Efeito dos tratamentos sobre a concentração ruminal

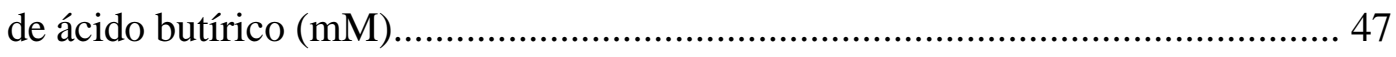

7 Efeito dos tratamentos sobre a relação acetato/propionato

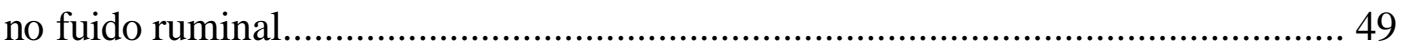




\section{LISTA DE QUADROS}

Página

1 Quadro esquemático de análise da variância para

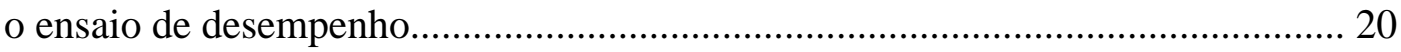

2 Quadro esquemático de análise da variância para

o ensaio de consumo e digestibilidade........................................................ 25

3 Quadro esquemático de análise da variância para $\mathrm{pH}, \mathrm{AGV}$ e $\mathrm{N}-\mathrm{NH}_{3} \ldots \ldots \ldots \ldots \ldots . . . . .26$ 


\section{LISTA DE TABELAS}

Página

1 Composição bromatológica e características físicas do BIN e BTPV ..................... 7

2 Estimativa da fibra fisicamente efetiva (FDNfe) dos alimentos utilizando medidas químicas e físicas de laboratório (\% MS) ............................. 12

3 Ajustes na concentração de FDN da ração total, considerando 30\% de FDN na MS como ponto médio inicial............................. 13

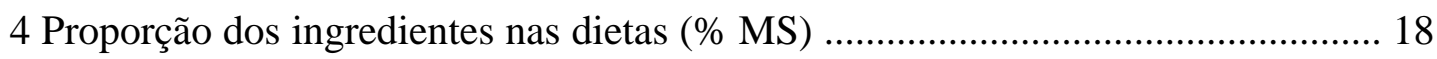

5 Composição bromatológica das dietas (\% MS) .................................................. 19

6 Efeito dos tratamentos sobre o consumo de matéria seca.................................... 27

7 Efeito dos tratamentos sobre o ganho de peso médio diário $(\mathrm{kg})$.......................... 29

8 Efeito dos tratamentos sobre a conversão alimentar.......................................... 29

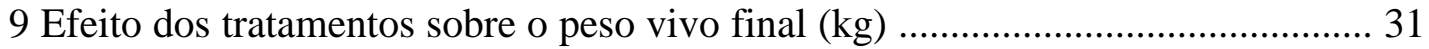

10 Composição bromatológica das dietas em porcentagem da MS......................... 31

11 Efeito dos tratamentos sobre o consumo voluntário e a digestibilidade aparente no trato total da matéria seca e da matéria orgânica............................... 33

12 Efeito dos tratamentos sobre o consumo e a digestibilidade aparente no trato digestivo total da fibra em detergente neutro

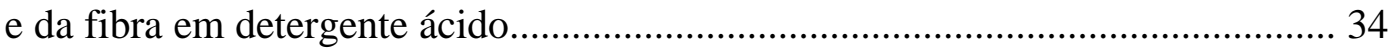

13 Efeito dos tratamentos sobre o consumo e a digestibilidade aparente da proteína bruta e extrato etéreo no trato digestivo total....................... 36

14 Efeito da substituição do BTPV pelo BIN sobre o $\mathrm{pH}$ ruminal........................... 37

15 Efeito dos tratamentos sobre a concentração de

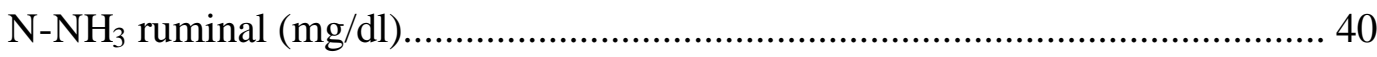

16 Efeito dos tratamentos sobre a concentração total de AGV no fluido ruminal $(\mathrm{mM})$ 
17 Efeito dos tratamentos sobre a concentração de acetato

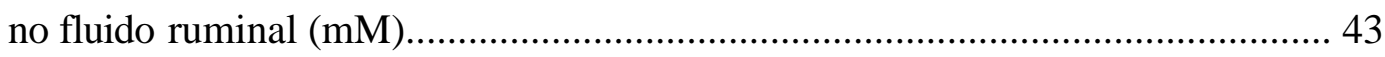

18 Efeito dos tratamentos sobre a concentração de propionato

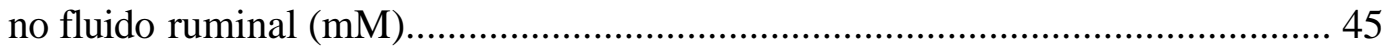

19 Efeito dos tratamentos sobre a concentração de butirato

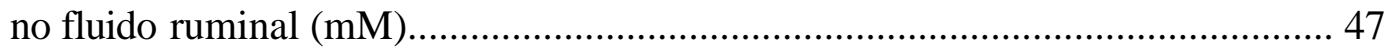

20 Efeito dos tratamentos sobre a relação acético/propiônico

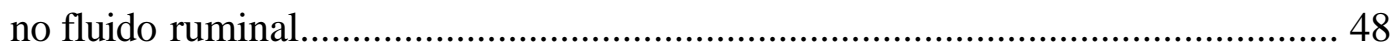

21 Efeito dos tratamentos sobre o comportamento ingestivo................................ 50 


\title{
EFEITOS DE FONTES E NÍVEIS DE FIBRA ÍNTEGRA, EM DIETAS CONTENDO BAGAÇO DE CANA-DE-AÇÚCAR TRATADO SOB PRESSÃO E VAPOR, SOBRE A DIGESTIBILIDADE, DESEMPENHO E COMPORTAMENTO INGESTIVO DE BOVINOS DE CORTE
}

\author{
Autor: MÁRIO MÁRCIO ARAKAKI RABELO \\ Orientador: Prof. Dr. ALEXANDRE VAZ PIRES
}

\section{RESUMO}

Avaliou-se o efeito de duas fontes de bagaço de cana-de-açúcar in natura (BIN) obtido por métodos diferentes de extração do açúcar (moagem convencional ou difusão), como fonte de fibra íntegra em dietas de bagaço tratado sob pressão e vapor (BTPV) como principal volumoso, sobre o desempenho, digestibilidade de nutrientes, parâmetros ruminais e comportamento ingestivo de bovinos de corte. No experimento I (ensaio de desempenho) foram utilizados 84 machos não castrados da raça Nelore $(n=24)$, Canchim $(n=24)$ e Holandesa $(n=36)$, com peso médio inicial de $270 \mathrm{~kg}$, sendo distribuídos em baias de acordo com a raça e o peso dos animais num delineamento em blocos casualizados. No experimento II (ensaio de digestibilidade e comportamento ingestivo) foram utilizados quatro garrotes mestiço Nelore com fístulas de rúmen e duodeno, peso médio inicial de $380 \mathrm{~kg}$ num delineamento em quadrado latino 4 x 4 . Os tratamentos consistiram na substituição direta do BTPV pelo BIN na matéria seca (MS) das dietas experimentais: 1) 5\% BIN moagem convencional; 2) 5\% BIN difusão; 3) $10 \%$ BIN difusão e 4) $15 \%$ BIN difusão. Não foi encontrada diferença $(\mathrm{P}>0,05)$ para o consumo de matéria seca, ganho de peso, conversão alimentar e peso vivo final entre os tratamentos no ensaio de desempenho. A utilização do BIN difusão até o nível mais elevado não apresentou efeito 
significativo $(\mathrm{P}>0,05)$ sobre a digestibilidade da $\mathrm{MS}$, matéria orgânica (MO), proteína bruta (PB), fibra em detergente neutro (FDN) e ácido (FDA) e extrato etéreo (EE) em comparação ao BIN moagem, porém reduziu $(\mathrm{P}<0,05)$ o consumo de MS, $\mathrm{MO}, \mathrm{PB}, \mathrm{FDN}$ e a digestibilidade em $\mathrm{kg}$ da MS e MO quando comparada com o BIN moagem. Não foi encontrada diferença $(\mathrm{P}>0,05)$ para os parâmetros ruminais $(\mathrm{pH}$, $\mathrm{N}-\mathrm{NH}_{3}, \mathrm{AGV}$, acetato, propionato, butirato e relação acetato/propionato) entre os tratamentos. $\mathrm{O}$ comportamento ingestivo foi influenciado pela maior participação de BIN difusão, registrando-se maiores tempos despendidos para as atividades de ingestão, ruminação e mastigação em minutos/kg de MS e FDN ( $\mathrm{P}<0,05)$. A adoção de BIN moagem determinou maior consumo de MS e menor tempo despendido com as atividades de ingestão e ruminação $(\mathrm{P}<0,05)$, resultando em maior tempo gasto na atividade de ócio $(\mathrm{P}=0,08)$. 


\title{
EFFECTS OF SOURCES AND LEVELS OF EFFECTIVE FIBER, IN STEAM PRESSURE SUGAR CANE BAGASSE BASED DIETS, ON DIGESTIBILITY, PERFORMANCE AND INGESTIVE BEHAVIOR OF BULL CALVES
}

\author{
Author: MÁRIO MÁRCIO ARAKAKI RABELO \\ Adviser: Prof. Dr. ALEXANDRE VAZ PIRES
}

\section{SUMMARY}

This study was conducted to evaluate the effects of substitution of steam pressure treated sugar cane bagasse by two types of raw bagasse extraction (grinding and diffusion), on performance, nutrient digestibilities, ruminal parameters and ingestive behavior. Performance trial used 84 bull calves weighting $270 \mathrm{~kg}$ at the beginning of experiment ("Nelore", "Canchim" and Holstein) in a Random Block Design. Digestibility and ingestive behavior trial used four bull calves cannulated in rumen and duodenum in a 4 x 4 Latin Square Design. Treatments were the substitution of steam pressure treated sugar cane bagasse by raw bagasse (RB): 1) $5 \% \mathrm{RB}$ from grinding; 2) 5\% RB from diffusion; 3) 10\% RB from diffusion and 4) $15 \%$ RB from diffusion. There was no effect $(\mathrm{P}>0,05)$ of fiber source or level on dry matter intake, weight gain, feed efficiency and final live weight in performance trial. Increasing $\mathrm{RB}$ from diffusion in the diets didn't affect $(\mathrm{P}>0,05)$ the dry matter, organic matter, crude protein, NDF, ADF and extract ether digestibilities, but reduced $(\mathrm{P}<0,05)$ dry matter, organic matter, crude protein and NDF intakes, besides dry matter and organic matter digestibilities $(\mathrm{kg})$ as compared with RB from grinding. There was no treatment effect $(\mathrm{P}>0,05)$ on ruminal $\mathrm{pH}$ and concentration of $\mathrm{N}-\mathrm{NH}_{3}$, acetate, propionate, butirate and VFA. The raw bagasse obtained by griding 
showed higher dry matter intake and less time spent with eating and chewing activities $(\mathrm{P}<0,05)$, while the rising levels of raw bagasse obtained by diffusion in the diets had higher spent time to eating, rumination and chewing activities in minutes/kg of dry matter and $\mathrm{NDF}(\mathrm{P}<0,05)$, resulting in less idling activities $(\mathrm{P}=0,08)$. 


\section{INTRODUÇÃO}

Os sistemas atuais para produção de bovinos de corte buscam níveis de produção e produtividade cada vez mais elevados buscando atender os vários segmentos consumidores da carne bovina, porém para alcançar esses patamares torna-se muitas vezes necessário em virtude da sazonalidade de produção de forragens, suplementar ou até mesmo confinar esses animais, o que onera demasiadamente o custo de produção da carne.

Uma das formas de reduzir tais custos é a utilização de resíduos da agroindústria. De acordo com Burgi (1997) o uso de subprodutos e resíduos concorre para a redução do custo das rações.

A utilização do bagaço de cana-de-açúcar tratado sob pressão e vapor como volumoso já é uma prática comum em confinamentos comerciais e várias pesquisas têm demonstrado o seu valor nutritivo e características intrínsecas deste alimento. Entre as peculiaridades deste alimento pode-se destacar o reduzido tamanho de partículas, o baixo $\mathrm{pH}$ e o baixo estímulo a ruminação podendo gerar problemas de metabolismo decorrentes desses fatores, prejudicando o desempenho dos animais. Várias alternativas são utilizadas para contornar esses problemas como a utilização de tamponantes químicos, ionóforos e fontes de fibra íntegra que auxiliam numa melhor utilização do bagaço de cana-de-açúcar tratado sob pressão e vapor pelos animais, em virtude da melhoria do ambiente ruminal para a digestão da fibra deste alimento.

Uma fonte de fibra íntegra que pode ser utilizada é o bagaço de cana-de-açúcar in natura obtido pela moagem convencional da cana-de-açúcar. Segundo Hausknecht (1996) seria interessante a realização de trabalhos para se determinar o nível ótimo de utilização desta fonte de fibra íntegra. 
As usinas que beneficiam a cana-de-açúcar dispõem de um método de extração do caldo rico em açúcares mais eficiente do que a moagem convencional, denominado de difusão, este método resulta num bagaço de cana-de-açúcar in natura com características diferentes, em virtude da eficiência dos processos, do bagaço de cana-deaçúcar in natura obtido pelas moendas. Dessa forma, este bagaço de cana-de-açúcar in natura obtido por difusão pode se apresentar como alternativa ao bagaço de cana-deaçúcar in natura proveniente de moendas, e servir como fonte de fibra íntegra em rações para bovinos de corte recebendo o bagaço de cana-de-açúcar tratado sob pressão e vapor como principal volumoso.

Diante do exposto, o presente trabalho objetivou avaliar a utilização do bagaço de cana-de-açúcar in natura resultante da difusão como fonte de fibra íntegra em níveis de 5, 10 e 15\% na matéria seca em substituição direta pelo bagaço de cana-de-açúcar tratado sob pressão e vapor e os efeitos dessa substituição sobre o desempenho, digestibilidade dos nutrientes, parâmetros ruminais e comportamento ingestivo. Como tratamento testemunha utilizou-se o bagaço de cana-de-açúcar in natura obtido por moagem convencional, em nível de 5\% na matéria seca. 


\section{REVISÃO DE LITERATURA}

\subsection{Bagaço de cana-de-açúcar tratado sob pressão e vapor}

O bagaço de cana-de-açúcar tratado sob pressão e vapor (BTPV) pode ser caracterizado como um alimento cujo tamanho médio de partículas é reduzido, alta concentração de ácidos orgânicos pré-formados, notadamente de ácido acético, e pH baixo, entre 3,6 e 4,3. Animais consumindo dietas baseadas neste alimento tem apresentado altos níveis de consumo e baixa atividade de ruminação. Estas características parecem indicar que, nestas dietas, o $\mathrm{pH}$ do trato gastrintestinal é um dos fatores limitantes ao desempenho dos animais (Lanna \& Boin, 1990; Carvalho et al. 1998).

De acordo com Mattos (1987) dietas com BTPV como principal volumoso caracterizam-se por propiciarem um ambiente ruminal desfavorável a digestão da fibra devido a elevada taxa de passagem deste alimento pelo rúmen e os baixos valores de $\mathrm{pH}$ observados no fluido ruminal.

O BTPV possui uma alta concentração de carboidratos solúveis que tem altas taxas de fermentação. Como a fibra presente no BTPV provoca pouco estímulo a ruminação, o tamponamento do rúmen é baixo e ocorre a queda do pH Hausknecht, 1996).

No tratamento do bagaço de cana-de-açúcar com pressão e vapor são três as variáveis manipuladas: pressão, temperatura e tempo de tratamento. $\mathrm{O}$ aumento da pressão determina elevação da digestibilidade. Por esse processo, a hemicelulose é quase totalmente solubilizada, pelo rompimento das ligações do tipo éster com a lignina, em que a liberação dos resíduos de ácido acético favorece a hidrólise. A 
lignina é parcialmente degradada provocando aumento de compostos fenólicos e furfural. $\mathrm{Na}$ segunda fase do processo, a descompressão rápida vaporiza a água presente no interior do hidrolisador, havendo afrouxamento da estrutura fibrosa da parede celular (Nussio \& Balsalobre, 1993).

Segundo Lanna et al. (1998) a eliminação da explosão (descompressão rápida) ao final da hidrólise pode evitar a redução no tamanho de partículas do BTPV, aumentando o tempo de permanência do BTPV no rúmen e, conseqüentemente, sua degradação efetiva. A eliminação da explosão também pode trazer vantagens na área industrial, com menor gasto de energia, pois permite reciclagem parcial do vapor, e menor desgaste dos equipamentos.

A diminuição da granulometria do BTPV durante o tratamento afeta o trânsito deste pelo trato digestivo, e inibe a formação de um emaranhado de fibras característico das dietas que apresentam fibra longa (Bulle, 2000). A falta desta camada no rúmen, responsável pela retenção de partículas pequenas de baixa digestibilidade, leva as partículas sólidas a deixar o rúmen mais rapidamente, sendo menos digeridas (Van Soest, 1994).

O uso de tratamento com pressão e vapor não seria indicado para o bagaço de cana-de-açúcar in natura (BIN) quando do uso de dietas de alta proporção de concentrado, pois o aumento da digestibilidade do bagaço obtido com esse tratamento é grandemente reduzido quando a dieta contém altas proporções de concentrado e o meio ruminal não é adequado para maximizar a digestão de fibras (Bulle, 2000).

De acordo com Lima \& Zanetti (1996) o bagaço de cana-de-açúcar tratado sob pressão e vapor pode ser usado em até $50 \%$ como fonte de volumoso único para bovinos em terminação, embora esses autores tenham utilizado $2 \%$ de aditivos tamponantes nas dietas experimentais.

Horton et al. (1991) testaram os efeitos sobre a digestibilidade e desempenho de dietas contendo bagaço de cana-de-açúcar in natura, BTPV, BTPV peletizado e BTPV amoniatado e peletizado. Os coeficientes de digestibilidade para MO, PB, celulose, FDN e FDA não foram afetados pelo tratamento sob pressão e vapor, mas foram reduzidos após a peletização. O BTPV peletizado até $15 \%$ da dieta não reduziu o desempenho de 
gado de corte em terminação alimentado com dietas com alto teor de concentrado. No entanto, Pate (1982) testando o tratamento sob pressão e vapor do bagaço de cana-deaçúcar sobre a digestibilidade e desempenho de novilhos de corte observou que os animais recebendo 32 e 56\% de BTPV como único volumoso exibiram deficiências por fibra, problema corrigido com a adição de feno.

Nesse sentido, Carvalho et al. (1998) cita que à medida que o nível de concentrado se eleva em dietas com base em BTPV, notadamente aquelas com alto teor de amido e açúcares, a condição ruminal tende a piorar. Para a correção desses problemas, Hausknecht (1996) propõe que uma maneira de melhorar o ambiente ruminal seria a utilização de uma fonte de fibra íntegra junto com o BTPV com o objetivo de provocar um maior estímulo à ruminação e com isso uma maior produção de saliva e um melhor tamponamento do rúmen.

$\mathrm{O}$ emprego de reagentes químicos $\left(\mathrm{Na}_{2} \mathrm{~S}, \mathrm{H}_{2} \mathrm{O}_{2}\right.$ e $\left.\mathrm{NaOH}\right)$ e uso de tratamento físico (pressão e vapor) incrementa a digestibilidade do bagaço de cana-de-açúcar, particularmente das frações fibrosas, o que resulta em maior valor de NDT, permitindo, dessa maneira, menor participação de alimento concentrado no arraçoamento animal (Manzano et al. 2000).

\subsection{Bagaço de cana-de-açúcar in natura}

O bagaço de cana-de-açúcar (BIN) é o produto resultante da moagem da cana-deaçúcar, processo que tem por finalidade a máxima extração do suco, ou seja, do conteúdo rico em açúcares, constituindo-se em alimento rico em parede celular, de baixo conteúdo celular, baixa digestibilidade, baixa densidade, pobre em proteínas e minerais (Santos, 1991).

A extração do caldo de cana-de-açúcar pode ser realizada através de moendas ou de aparelhos chamados difusores, obtendo-se deste modo bagaço in natura com características físicas e químicas diferentes. A extração que, de 90 a $93 \%$ obtida pelas moendas convencionais, passa a ser de 96 a $98 \%$ pelo processo de difusão (Delgado et al. 1975). 
A "difusão" consiste em se comprimir a cana-de-açúcar ao máximo e, a sacarose aderida ao material fibroso é dissolvida e removida por lixiviação (lavagem), através de difusores. A fim de se reduzir a quantidade de água necessária, procede-se uma operação de retorno, assim ao final da operação, quando o bagaço de cana-de-açúcar se apresenta exaurido ao máximo, faz-se a lavagem com água fresca. O líquido obtido desta lavagem, contendo alguma sacarose que conseguiu-se extrair do bagaço é usado na lavagem do bagaço anterior que é um pouco mais rico e, assim, sucessivamente. Esse retorno pode ser efetuado de 5 a 20 vezes, dependendo do grau de esgotamento desejado (Delgado et al. 1975).

A extração do caldo de cana-de-açúcar pelos difusores é realizada pelo efeito combinado de osmose e lixiviação, embora a participação da osmose seja considerada pequena e restrita aos tecidos fechados (Delgado et al. 1975).

De acordo com Beltrame Filho (1998) o bagaço de cana-de-açúcar in natura não se caracteriza como uma boa fonte de fibra íntegra devido a grande proporção de partículas de pequeno tamanho e a possibilidade de crescimento de fungos. A baixa densidade do BIN aliado a um reduzido valor comercial limitam seu transporte a médias e longas distâncias (Berndt, 2000). Segundo este mesmo autor, o bagaço de cana-deaçúcar in natura com apenas 30\% de NDT e baixa quantidade de proteína, indisponível ao animal por estar ligada às frações fibrosas do alimento, não representa um alimento com bom potencial de fornecer nutrientes ao animal. Entretanto, o autor sugere a possível utilização deste alimento como fornecedor da fibra necessária à digestão de bovinos de corte. Na Tabela 1 são apresentados os valores da composição bromatológica, mineral e características físicas do BTPV e do BIN de acordo com Burgi (1985) e Nussio \& Balsalobre (1993).

Thiago et al. (1983) avaliando a substituição da ponta de cana pelo BIN em níveis de até $40 \%$ na MS, observaram redução no desempenho de novilhos em engorda, os autores sugerem o uso de no máximo $20 \%$ da MS de BIN na dieta. Igualmente, Burgi (1985) observou retração no consumo de bovinos utilizando 60\% de BIN na MS, segundo o autor provavelmente ocorreu uma limitação física do consumo devido ao enchimento do trato digestivo com um material muito volumoso e pouco denso. 
Ezequiel \& Andrade (1988) avaliando a ingestão e digestibilidade de rações contendo bagaço de cana-de-açúcar in natura, palha de arroz e fenos de capins tropicais como volumosos e três níveis de concentrados (20, 40 e 60\%) concluíram que a introdução do bagaço de cana-de-açúcar limitou a ingestão voluntária das rações e que a utilização de bagaço de cana-de-açúcar afeta negativamente a utilização da fibra bruta e da matéria-seca das rações.

Tabela 1. Composição bromatológica e características físicas do BIN e BTPV

\begin{tabular}{|c|c|c|}
\hline & $\mathrm{BIN}^{1}$ & $\mathrm{BTPV}^{2}$ \\
\hline $\mathrm{MS}(\%)$ & $43,2-48,2$ & 40,32 \\
\hline $\mathrm{pH}$ & 5,5 & 3,0 \\
\hline Densidade $\left(\mathrm{kg} / \mathrm{m}^{3}\right)$ & $100-150$ & $300-400$ \\
\hline Friabilidade & $(-)$ & $(+)$ \\
\hline DVIVMS (\%) & 33,0 & 64,8 \\
\hline \multicolumn{3}{|l|}{ Composição (\% MS) } \\
\hline Proteína bruta & 1,86 & 1,67 \\
\hline Fibra bruta & $45-47$ & 34,5 \\
\hline Extrato etéreo & 2,26 & 4,86 \\
\hline Matéria mineral & 2,73 & 4,77 \\
\hline FDA & $62,3-63,4$ & 62,65 \\
\hline FDN & $85,2-94,8$ & 58,16 \\
\hline Celulose & 44,69 & 43,99 \\
\hline Hemicelulose & 22,91 & - \\
\hline Lignina em detergente ácido & 14,89 & 15,06 \\
\hline $\mathrm{Ca}$ & - & 0,12 \\
\hline $\mathrm{P}$ & - & 0,02 \\
\hline K & - & 0,16 \\
\hline S & - & - \\
\hline Fenol & 0,4 & 7,2 \\
\hline
\end{tabular}

\footnotetext{
${ }^{1}$ Bagaço de cana-de-açúcar in natura $;{ }^{2}$ Bagaço de cana-de-açúcar tratado sob pressão e vapor.
} 
Lanna \& Boin (1990) testando o bagaço de cana-de-açúcar in natura associado ou não ao bicarbonato de sódio como substituto do feno de gramínea como fonte de fibra longa para rações de bovinos balanceadas com altas proporções de BTPV concluíram que o baixo $\mathrm{pH}$ do BTPV $(2,9$ a 3,4) e a aparente baixa atividade de ruminação observados indicam que o $\mathrm{pH}$ do rúmen e trato digestivo inferior é um fator limitante em dietas com altas proporções de BTPV, sendo que a substituição do feno de "Rhodes" pelo BIN sem a adição de bicarbonato de sódio reduziu a ingestão de matéria seca e o ganho de peso dos machos, não existindo efeito sobre as fêmeas.

Também, Hausknecht (1996) avaliando dietas a base de BTPV (43,4\% na MS) associado ao BIN $(8,0 \%)$ ou a cana-de-açúcar inteira picada $(8,0 \%)$ como fontes de fibra íntegra concluiu que a inclusão de cana-de-açúcar nas proporções utilizadas tem um efeito positivo sobre o consumo e ganho de peso dos animais, e que a proporção de BIN utilizada parece ter sido acima do desejado, prejudicando o desempenho.

Beltrame Filho (1998) trabalhando com dietas de alta proporção de concentrados não obteve problemas como laminite ou acidose clinica nos animais alimentados com até $12 \%$ de BIN na matéria-seca.

Carvalho et al. (1998) testando a substituição parcial do milho por subprodutos energéticos em dietas de novilhos, tendo o BTPV como volumoso principal, encontraram valores de $\mathrm{pH}$ que permaneceram em níveis aceitáveis para permitir a degradação de fibra, inclusive acima dos valores preditos pelo CNCPS 3.0. Os autores sugeriram que a presença de 5\% de bagaço de cana-de-açúcar in natura, o uso de calcário calcítico de alta reatividade, a utilização de monensina sódica e o fornecimento de dois tratos diários contribuíram para minimizar a queda do $\mathrm{pH}$ ruminal.

\subsection{A fibra na nutrição de ruminantes}

A fibra representa a fração de carboidratos dos alimentos de digestão lenta ou indigestível e, dependendo de sua concentração e digestibilidade, impõe limitações sobre o consumo de matéria seca e energia. Por outro lado, a saúde dos ruminantes também 
depende diretamente de concentrações mínimas de fibra na ração que permitam manter a atividade de mastigação e a motilidade do rúmen (Nussio et al. 2000).

De acordo com Eastridge (1997) a extensa fermentação no rúmen resulta em um abundante suprimento de nutrientes para o ruminante e facilita a utilização de uma variedade de alimentos, sendo a função mais crítica desta fermentação a digestão dos componentes fibrosos das plantas.

A quantidade de fibra nas dietas para ruminantes foi analisada primeiramente pelo método de fibra bruta (FB) aprovado pelo A.O.A.C. em 1962. Van soest \& Wine (1967) por sua vez desenvolveram o sistema de fibra em detergente neutro (FDN) e fibra em detergente ácido (FDA). As diferenças nas proporções e nas configurações intermoleculares dos componentes da fibra fazem com que nenhuma das fibras (FB, FDA ou FDN) tenha propriedades nutricionais constantes (Mertens, 1992).

Este mesmo autor propôs a classificação dos carboidratos em fibrosos (hemicelulose, celulose e lignina) e não fibrosos (amidos, açúcares e pectinas), esta classificação leva em conta os aspectos nutricionais mais do que as características químicas ou funções exercidas nas plantas (carboidratos estruturais e não estruturais). A pectina (carboidrato estrutural) é rapidamente digerida no rúmen e não tem valor fibroso algum.

A porção FDN mede as características químicas, mas não as características físicas da fibra, tais como, tamanho de partícula e densidade. Essas características físicas podem influenciar a saúde animal, fermentação ruminal, metabolismo animal e produção de gordura no leite independentemente do total ou composição química da FDN medida (Mertens, 1996).

A utilização da FDN para medir a fibra dos alimentos é problemática em duas classes: forragens processadas em diferentes formas físicas e subprodutos com alto teor de fibra (Armentano \& Pereira, 1997).

As diferenças no total e nas propriedades físicas da fibra podem afetar a utilização da dieta e o desempenho animal. Quando muita fibra é incluída na ração, a densidade energética é baixa, a ingestão é reduzida e a produtividade diminui. Quando pouca fibra é incluída, uma variedade de sintomas pode ocorrer, variando desde uma 
alteração de fermentação no rúmen até uma severa acidose resultando em morte (Mertens, 1996). O NRC (1989) indica pelo menos 19 e $21 \%$ de FDA e 25 e $28 \%$ de FDN para vacas no pico e início de produção de leite, respectivamente, e que pelo menos $75 \%$ da porção FDN das dietas seja proveniente de forragens.

Segundo Eastridge (1997) a FDN da forragem parece ser uma das melhores medidas simples do nível adequado de fibra, e o nível mínimo de FDN da forragem deve ser entre 15 e $20 \%$ da MS, entretanto, o nível mínimo de FDN da forragem pode depender do nível de carboidratos não fibrosos na dieta.

A digestibilidade da fibra depende de características químicas e físicas. As principais características químicas relacionadas a digestibilidade da fibra são a composição e relação entre carboidratos estruturais e concentração de lignina. As características físicas como densidade, capacidade de troca de cátions, poder tampão e hidratação de partículas estão relacionadas ao tempo de colonização de partículas "lag time" e taxa de digestão. Além disso, o acesso de microorganismos do rúmen a parede celular secundária também é determinante do aproveitamento de fibra por ruminantes (Nussio et al. 2000).

A digestibilidade ruminal dos componentes da dieta e a remoção dos produtos finais da fermentação são influenciadas pela taxa de passagem da fase líquida e sólida. São muitos os fatores que podem determinar a taxa de passagem, incluindo o nível de consumo e as características físicas e químicas da dieta (Allen, 1994; Eastridge, 1997).

\subsection{Efetividade de fibra}

Mertens (1996) distinguiu FDN fisicamente efetivo e FDN efetivo com base nas seguintes definições: o FDN fisicamente efetivo está relacionado às características físicas da fibra (primeiramente tamanho de partícula) que influenciam a atividade de mastigação e a natureza bifásica do conteúdo ruminal (partículas maiores flutuantes sobre um "pool" de líquido e partículas pequenas). 
Já o FDN efetivo está relacionado ao somatório total da habilidade de um alimento repor a forragem ou fibra numa ração para que a porcentagem de gordura no leite produzida por vacas comendo um tipo de ração seja efetivamente mantida.

Allen (1997) descreve fibra fisicamente efetiva como a fração do alimento que estimula a atividade de mastigação. A mastigação por sua vez estimula a secreção de saliva, os tamponantes na saliva (bicarbonato e fosfato) neutralizam os ácidos produzidos pela fermentação da matéria orgânica no rúmen. O balanço entre os ácidos produzidos na fermentação e a secreção de tamponantes é o maior determinante do $\mathrm{pH}$ ruminal, e este por sua vez em baixos valores pode reduzir o consumo de matéria seca, digestibilidade de fibra e produção microbiana.

De acordo com Eastridge (1997) a produção de saliva está relacionada com o tempo de mastigação, que é uma função do consumo de forragem e tamanho de partícula e que o "mat" ruminal serve como um separador do tamanho das partículas, resultando no alojamento das partículas que necessitam ser mais digeridas e conclui que a consistência do "mat" ruminal pode afetar a digestibilidade e a passagem da fase sólida do alimento.

Mertens (1997) propôs um sistema para se avaliar a FDN fisicamente efetiva, considerando as características químicas e físicas dos alimentos, o autor utiliza a concentração de FDN do alimento (\%MS) e multiplica este valor pela quantidade de partículas retidas em peneira maior do que $1,18 \mathrm{~mm}$, sendo o produto desta operação o valor de FDN fisicamente efetivo como demonstrado na Tabela 2.

$\mathrm{O}$ valor de $1,18 \mathrm{~mm}$ baseia-se no tamanho de partículas encontradas nas fezes em alguns trabalhos citados por Mertens (1997), este tamanho de partícula teria pouca influência sobre a atividade de mastigação passando pelo rúmen sem a necessidade de ruminação. Entretanto, Queiroz et al. (1996) não recomendam utilizar o tamanho de partículas nas fezes como indexador do tamanho crítico das partículas da digesta que abandonam o retículo-rúmen, pois tais partículas sofrem degradação em cada seção do trato digestivo. 
Tabela 2. Estimativa da fibra fisicamente efetiva (FDNfe) dos alimentos utilizando medidas químicas e físicas de laboratório (\% MS).

\begin{tabular}{lccc}
\hline Alimento & FDN & $\begin{array}{c}\text { \% retida em } \\
1,18 \mathrm{~mm}\end{array}$ & FDNfe \\
\hline Padrão & 100 & 1,00 & 100,0 \\
Feno de gramínea & 65 & 0,98 & 63,7 \\
Feno de leguminosa & 50 & 0,92 & 46,0 \\
Silagem de milho & 51 & 0,81 & 41,5 \\
Milho moído & 9 & 0,48 & 4,3 \\
Farelo de soja & 14 & 0,23 & 3,2 \\
\hline
\end{tabular}

Fonte: Adaptado de Mertens (1997).

Allen (1996) propõe uma série de ajustes na concentração de FDN para vacas em lactação, levando-se em conta fatores físicos, químicos, nutricionais e de manejo, considerando uma ração com $30 \%$ de FDN na matéria-seca como ponto médio inicial (Tabela 3).

A efetividade física é um componente importante do valor da fibra, mas não é o único. Numa tentativa de se obter uma medição mais completa da fração FDN efetivo, as respostas dos animais que integram as características físicas e não físicas dos carboidratos nas dietas podem ser usadas como variável resposta (Armentano \& Pereira, 1997).

Estes autores têm utilizado a porcentagem de gordura no leite para definir um valor de efetividade física (ef) e FDN efetivo (FDN efetivo $=$ ef $\times$ FDN), mas também sugerem o pH ruminal ou padrões dos ácidos graxos voláteis como respostas dos animais que integram os múltiplos componentes de fibra efetiva existente na ração.

De acordo com Bulle (2000) a redução do tamanho de partículas tem profundas implicações para a dinâmica da digestão do BTPV, pois reduz o teor de FDN efetivo com conseqüente redução do efeito de fibra íntegra. 
Tabela 3. Ajustes na concentração de FDN da ração total, considerando 30\% de FDN na MS como ponto médio inicial.

\begin{tabular}{|c|c|}
\hline Fator & Ajuste recomendado (\% FDN na MS) \\
\hline Tamanho de partículas & $\begin{array}{l}\text { - Sem ajustes para silagens quando } 5 \text { a } 10 \% \\
\text { de partículas }>19 \mathrm{~mm} \text {. } \\
\text { - Redução de duas unidades percentuais } \\
\text { quando a forragem contem mais de } 15 \% \text { das } \\
\text { partículas maiores que } 19 \mathrm{~mm} \text {. } \\
\text { - Aumento de } 2 \% \text { quando a forragem } \\
\text { contem poucas partículas > } 19 \mathrm{~mm} \text {. } \\
\text { - Aumento de } 4 \% \text { quando forragens são } \\
\text { picadas finamente. }\end{array}$ \\
\hline Freqüência de fornecimento de grãos & $\begin{array}{l}\text {-Redução de } 1,5 \% \text { quando o fornecimento é } \\
\text { > que quatro vezes ao dia. } \\
\text {-Aumento de } 1,5 \% \text { quando o fornecimento é } \\
\text { igual ou inferior a duas vezes por dia. }\end{array}$ \\
\hline Digestibilidade ruminal do amido & $\begin{array}{l}\text { - Sem ajuste, caso a digestibilidade esteja } \\
\text { entre } 75 \text { e } 80 \% \text {. } \\
\text { - Redução de } 2 \% \text {, caso a digestibilidade } \\
\text { esteja entre } 65 \text { e } 75 \% \text {. } \\
\text { - Aumento de } 2 \% \text {, caso a digestibilidade } \\
\text { seja superior a } 80 \% \text {. }\end{array}$ \\
\hline Digestibilidade da fibra & $\begin{array}{l}\text { - Aumento de } 2 \% \text { quando forragem de alta } \\
\text { digestibilidade de FDN for fornecida. }\end{array}$ \\
\hline Inclusão de subprodutos & $\begin{array}{l}\text { - Aumento de } 2 \% \text { quando subprodutos } \\
\text { fibrosos de partículas pequenas forem } \\
\text { fornecidos em até } 10 \% \text { da MS. }\end{array}$ \\
\hline Uso de tamponantes & - Redução de 0,5 a 1,0\% da MS. \\
\hline
\end{tabular}

Fonte: Adaptado de Allen (1996).

Mertens (1999) sugeriu 21\% de FDN fisicamente efetivo para se manter o $\mathrm{pH}$ ruminal acima de 6,0 e o teor de gordura no leite em 3,4\%. Esse valor proposto pode variar de 19 a $23 \%$ dependendo de fatores que afetem a atividade de mastigação, 
produção de ácidos no rúmen, variações na composição e manejo da dieta, capacidade natural de tamponamento do rúmen e suplementação com substâncias tamponantes.

O CNCPS 3.0 aplica a metodologia proposta por Mertens (1997) ajustando-a com outros fatores como manejo e composição da dieta, sendo que a exigência de FDNfe (\%MS) pode variar de 5 a $8 \%$ para dietas com bom manejo de cocho e uso de ionóforos, e até $20 \%$ de FDNfe para dietas com manejo variável e sem uso de ionóforos ou dietas para maximizar o uso de carboidratos não fibrosos e produção de proteína microbiana em dietas para gado de corte em terminação.

Segundo Loerch (1997) para animais em crescimento destinados ao abate, as exigências de fibra não são de grande importância, pois são alimentados com dietas à base de concentrado por um período de tempo relativamente curto, e se os problemas de saúde ruminal se desenvolverem não serão problemas maiores, já que os animais estão sendo alimentados para serem abatidos.

Embora dietas com até $100 \%$ de concentrado tenham sido utilizadas com sucesso para bovinos de corte, a adição de cerca de 5 a $20 \%$ da matéria-seca da dieta com uma fonte de fibra parece melhorar o desempenho animal (Preston, 1998).

\subsection{Digestão da parede celular}

Em revisão de diversos trabalhos sobre a degradação da forragem no rúmen, Thiago \& Gill (1990) mencionan que as células das plantas são delimitadas por um invólucro visível chamado parede celular, cujo principal componente é a celulose, presente na forma de uma malha estrutural denominada microfibrilas. Estas microfibrilas podem estar organizadas de forma irregular ou irregular, e os espaços entre elas podem estar preenchidos com lignina, suberina, cutina e outros compostos, cuja concentração e distribuição influenciam no processo de degradação da parede celular. Dessa forma, a resistência da parede celular a degradação microbiana não está somente relacionada a concentração dos agentes inibidores da digestão (detectados quimicamente), mas também a sua forma de distribuição, o que talvez explique a existência de um melhor 
relacionamento do consumo voluntário com o teor dos componentes da parede celular do que com a digestibilidade.

De acordo com esses autores, a fixação das bactérias do rúmen na parede celular das plantas antes da sua degradação parece ocorrer mediante uma densa matriz extracelular que adere firmemente a bactéria à célula. Esta matriz extracelular, denominada "glycocalyx" consiste de filamentos externos que podem moldar-se a superfície do substrato. Os tecidos de mais fácil degradação são de rápido desaparecimento, resultando em maior presença de substratos fermentáveis no rúmen, o que vem favorecer maior degradação através de secreções enzimáticas extracelulares da bactéria, sem a necessidade de sua fixação prévia as células constituintes dos diversos tecidos da planta.

Em continuação, foi destacado que com tecidos mais digestíveis (parênquima e floema), a degradação ocorre sem a necessidade da fixação das bactérias as células, mas a degradação dos tecidos menos digestíveis (xilema e tecidos epidermais) somente ocorre após a completa fixação da bactéria. Fato mencionado por Fahey \& Berger (1988) que expõem as diferenças dos carboidratos nas plantas e a variação na susceptibilidade as enzimas produzidas pelos microorganismos ruminais.

Segundo Balsalobre et al. (1999) a depender da idade fisiológica da cana-deaçúcar no momento do corte, o teor de FDN pode variar de 40 a 65\%, porém, próximo da idade ideal de corte essa variação é menor e que uma forma de aumentar o aproveitamento de alimentos de maior proporção de parede celular, como no caso da cana-de-açúcar, é torná-la mais exposta ao ataque dos microorganismos ruminais, ou seja, executar uma boa picagem do material. No entanto, o autor ressalta que o material finamente picado pode trazer problemas de efetividade de fibra, chegando a provocar problemas metabólicos.

De acordo com Van Soest (1994) a lignina interfere na taxa e extensão de digestão e que os efeitos da maturidade da planta são confundidos com o tempo e o aparente aumento da lignificação, dessa forma a taxa e extensão de digestão estão associadas com o declínio da qualidade das forragens com a maturidade. O mesmo autor comenta que gramíneas e leguminosas de igual digestibilidade são particularmente 
dessemelhantes, considerando que a parede celular das leguminosas contêm aproximadamente o dobro de lignina e é muito menos digestível, mas fermenta mais rapidamente do que gramíneas no mesmo estágio de crescimento, segundo o autor as diferenças podem ser em virtude do maior conteúdo em hemicelulose das gramíneas, ou talvez porque as respectivas ligninas são muito diferentes em suas constituições. 


\section{MATERIAL E MÉTODOS}

O trabalho constou da realização de dois experimentos: Experimento I - ensaio de desempenho e Experimento II - ensaio de digestibilidade, avaliação de parâmetros ruminais e comportamento ingestivo.

\subsection{Experimento I - Ensaio de desempenho}

\subsubsection{Animais e instalações experimentais}

Foram utilizados 84 machos não castrados das raças Nelore $(n=24)$, Canchim ( $\mathrm{n}=24)$ e Holandesa $(\mathrm{n}=36)$, com peso médio inicial em torno de $270 \mathrm{~kg}$, sendo distribuídos três animais em cada baia, num total de 28 baias, de acordo com a raça e o peso inicial, em um delineamento em blocos casualizados. $\mathrm{O}$ experimento foi conduzido nas instalações experimentais de bovinos do Departamento de Produção Animal da ESALQ/USP, durante o período de Outubro de 1999 a Fevereiro de 2000. As baias dispunham de cobertura, com piso, cocho e bebedouros de concreto.

Os animais foram previamente everminados e receberam uma dose de complexo vitamínico ADE na fase de adaptação as dietas e as instalações experimentais.

\subsubsection{Dietas experimentais}

Os tratamentos avaliados foram: bagaço cru de cana-de-açúcar in natura (moagem ou difusão) e os níveis do bagaço cru in natura resultante do processo de 
difusão, em substituição ao BTPV, em proporção direta na matéria seca das dietas experimentais, constituindo-se em:

1. $45 \%$ Bagaço tratado sob pressão e vapor : $5 \%$ BIN (moagem);

2. $45 \%$ Bagaço tratado sob pressão e vapor : $5 \%$ BIN (difusão);

3. $40 \%$ Bagaço tratado sob pressão e vapor : $10 \%$ BIN (difusão);

4. $35 \%$ Bagaço tratado sob pressão e vapor : $15 \%$ BIN (difusão);

A relação volumoso: concentrado foi de 50 : 50. A proporção dos ingredientes das dietas e a composição bromatológica são apresentadas nas Tabelas 4 e 5.

Tabela 4. Proporção dos ingredientes nas dietas (\% MS).

\begin{tabular}{lcccc}
\hline \multirow{2}{*}{ Ingredientes } & \multicolumn{4}{c}{ Tratamentos } \\
\cline { 2 - 5 } BTPV $^{3}$ & $5 \%$ BINmoa $^{1}$ & $5 \%$ BINdif $^{2}$ & $10 \%$ BINdif & $15 \%$ BINdif \\
BIN $^{4}$ & 5,00 & 45,00 & 40,00 & 35,00 \\
Sorgo moído & 5,00 & 5,00 & 10,00 & 15,00 \\
Levedura & 8,00 & 32,50 & 32,50 & 32,50 \\
Farelo de soja & 6,00 & 6,00 & 8,00 & 8,00 \\
Uréia & 1,00 & 1,00 & 6,00 & 6,00 \\
Minerais & 2,50 & 2,50 & 1,00 & 1,00 \\
\hline
\end{tabular}

\footnotetext{
${ }^{1}$ Bagaço in natura - método de moagem convencional; ${ }^{2}$ Método de difusão.
}

${ }^{3}$ Bagaço de cana-de-açúcar tratado sob pressão e vapor; ${ }^{4}$ Bagaço in natura

Os concentrados foram misturados previamente em um misturador horizontal (marca Lucato, com capacidade de $500 \mathrm{~kg}$ ). O bagaço in natura e o bagaço tratado sob pressão e vapor foram estocados a granel sob galpões e compactados evitando-se o aparecimento de fungos e perdas das características desses alimentos. Por época do fornecimento das dietas os volumosos e os concentrados, nas suas respectivas proporções, foram misturados através de vagão para ração completa (marca Siltomac, 
com capacidade de $1800 \mathrm{Kg}$ ) e fornecidos como ração completa diariamente as 18:00 horas, ad libitum, permitindo-se sobras ao redor de $10 \%$, que foram registradas semanalmente.

Tabela 5. Composição bromatológica das dietas (\% MS).

\begin{tabular}{lcccc}
\hline \multirow{2}{*}{ Composição } & \multicolumn{4}{c}{ Tratamentos } \\
\cline { 2 - 5 } & $5 \%$ BINmoa $^{1}$ & $5 \%$ BINdif $^{2}$ & $10 \%$ BINdif & 15\% BINdif \\
\hline Matéria seca & 69,9 & 68,6 & 71,4 & 70,2 \\
Proteína bruta & 12,8 & 12,8 & 12,8 & 12,8 \\
NDT $^{3}$ & 63,2 & 63,2 & 62,7 & 62,2 \\
Cálcio & 0,66 & 0,66 & 0,66 & 0,66 \\
Fósforo & 0,29 & 0,29 & 0,29 & 0,29 \\
\hline
\end{tabular}

${ }^{1}$ Bagaço in natura - método de moagem convencional; ${ }^{2}$ Método de difusão.

${ }^{3}$ Nutrientes digestíveis totais

\subsubsection{Período experimental}

O experimento teve a duração de 150 dias, sendo os primeiros trinta dias destinados ao processo de adaptação dos animais as instalações e as dietas experimentais, e o restante do período foi segmentado em quatro sub-períodos de trinta dias. Os animais foram pesados no início e no final de cada sub-período, sendo determinados o ganho de peso, a conversão alimentar, consumo de matéria seca e o peso vivo final das unidades experimentais.

\subsubsection{Coletas de dados referentes ao consumo de matéria seca}

Os dados de consumo de matéria seca foram obtidos através da diferença entre a quantidade de matéria seca fornecida e a verificada nas sobras. A quantidade de matéria seca oferecida era mensurada diariamente com a utilização da balança eletrônica do 
vagão para ração completa, sendo a quantidade ofertada diariamente baseada nas sobras do dia anterior, após a limpeza dos cochos e pesagem de sobras.

\subsubsection{Análise estatística}

O ensaio de desempenho foi conduzido num delineamento experimental em blocos casualizados de acordo com a raça e o peso inicial dos animais, constando de sete blocos. Adotou-se para análise estatística o procedimento GLM do programa estatístico SAS (1997), analisando-se as diversas variáveis dentro de cada sub-período, utilizandose o peso inicial como covariável. O quadro da análise da variância é mostrado no Quadro 1.

\begin{tabular}{lc}
\hline Causa de variação & Graus de liberdade \\
\hline Tratamentos & 3 \\
Blocos & 6 \\
Peso inicial & 1 \\
Resíduo & 17 \\
Total & 27 \\
\hline Quadro 1- Quadro esquemático de análise da variância para o ensaio de desempenho.
\end{tabular}

Quadro 1- Quadro esquemático de análise da variância para o ensaio de desempenho.

\subsection{Experimento II - Ensaio de digestibilidade e avaliação de parâmetros ruminais}

\subsubsection{Animais e instalações experimentais}

Utilizou-se quatro garrotes mestiços Nelore com cânulas no rúmen e duodeno, com peso médio inicial em torno de $380 \mathrm{~kg}$, distribuídos em um quadrado latino 4x4. O experimento foi conduzido nas instalações experimentais de bovinos do Departamento de Produção Animal da ESALQ/USP, durante o período de Outubro de 2000 a Janeiro de 2001. Os animais foram alojados em baias individuais cobertas, do tipo "tie stall", providas de bebedouros automáticos e cocho para a alimentação. 


\subsubsection{Dietas experimentais}

As dietas experimentais tiveram composição idêntica as dietas do ensaio de desempenho. As dietas foram misturadas manualmente e fornecidas duas vezes ao dia (6:30 e 18:30 horas), ad libitum, admitindo-se sobras ao redor de 5\%.

\subsubsection{Período experimental}

O experimento teve a duração de 90 dias, sendo os primeiros trinta dias destinados adaptação dos animais as instalações e as dietas experimentais, e o restante do período foi dividido em quatro sub-períodos de 15 dias, sendo destinado os onze primeiros dias dos sub-períodos para a adaptação dos animais as novas dietas e os quatro últimos para as coletas de dados e amostras.

\subsubsection{Coleta de dados referentes ao consumo de matéria seca}

As amostras das dietas fornecidas e das sobras do décimo primeiro ao décimo quinto dia foram amostradas uma vez por dia e compostas por animal dentro de cada período.

Após as coletas as amostras eram congeladas a $-10^{\circ} \mathrm{C}$, visando a sua conservação, para posterior secagem em estufa com ventilação forçada $\left(55^{\circ} \mathrm{C}\right)$, por 72 horas, para determinação do teor de matéria seca de acordo com o A.O.A.C. (1990).

\subsubsection{Coleta de amostras para determinação da digestibilidade aparente no trato digestivo total}

A digestibilidade dos nutrientes foi determinada através da diferença entre a quantidade de nutrientes presentes no material consumido pelos animais e a quantidade desses mesmos nutrientes nas fezes. Para isso, foram coletadas durante os quatro últimos 
dias de cada sub-período, amostras do oferecido e sobras, com intervalos de doze horas, sendo essas compostas por animal em cada período. Além disso, procedeu-se a pesagem do total de fezes excretadas pelos animais nos quatro últimos dias de cada sub-período, sendo essas amostradas e compostas por animal por dia, para a determinação da quantidade de matéria seca em $\mathrm{kg}$ excretadas nas fezes.

As amostras de oferecido, sobras e fezes, foram conservadas por congelamento a $-10^{\circ} \mathrm{C}$, para posterior determinação de matéria seca (MS), matéria orgânica (MO), proteína bruta (PB), fibra detergente neutro (FDN), fibra detergente ácido (FDA), lignina, extrato etéreo (EE) e matéria mineral (MM). A digestibilidade dos nutrientes foi calculada da seguinte forma :

Digestibilidade do nutriente (\%)

$=(\mathrm{kg}$ do nutriente consumido $-\mathrm{kg}$ do nutriente nas fezes $) \times 100$

$\mathrm{kg}$ do nutriente consumido

\subsubsection{Coleta de amostras para determinação da digestibilidade aparente no rúmen e intestinos}

Inicialmente a digestibilidade aparente no rúmen e intestinos seria determinada através da utilização do óxido de cromo $\left(\mathrm{Cr}_{2} \mathrm{O}_{3}\right)$, como marcador externo de indigestibilidade, sendo esse fornecido no rúmen duas vezes por dia $(5,0 \mathrm{~g} /$ dose a cada 12 horas), via cânula ruminal, 10 dias antes do término das coletas de cada período.

As amostras do conteúdo duodenal $(n=24)$, foram coletadas a cada 4 horas, com tempo inicial avançado de $1 \mathrm{~h}$, em cada dia de cada período. Após as coletas as amostras eram compostas por animal e por período, congeladas $-10^{\circ} \mathrm{C}$, visando a sua conservação, para posterior secagem em estufa com ventilação forçada $\left(55^{\circ} \mathrm{C}\right)$, por 72 horas e moídas em moinhos do tipo Wiley providos de peneiras de 2 e $1 \mathrm{~mm}$, para determinação de $\mathrm{N}$, EE, FDN, FDA, lignina, MO e cromo. 
A digestibilidade no rúmen e intestinos seria calculada através da concentração dos nutrientes e do marcador externo de indigestibilidade no alimento consumido e no conteúdo duodenal. No entanto, os resultados apresentados pelas análises não foram satisfatórios e condizentes com a literatura, não sendo possível definir a causa dos problemas da recuperação do cromo e conseqüente impedimento da determinação da digestibilidade aparente do rúmen e intestinos. A análise de cromo utilizada é descrita por Silva (1981).

\subsubsection{Análise bromatológica das dietas, sobras e fezes}

A metodologia utilizada para a preparação das amostras para as análises laboratoriais das dietas oferecidas e sobras já foram descritas anteriormente, dessa forma será dada ênfase apenas para o procedimento de coleta e preparação das amostras de fezes.

As amostras de fezes foram coletadas a cada 8 horas, com tempo inicial avançado em duas horas por dia de cada período do décimo primeiro ao décimo quarto dia de cada período de coleta. Após as coletas as amostras eram compostas por animal e por período, congeladas $-10^{\circ} \mathrm{C}$, visando a sua conservação, para posterior secagem em estufa com ventilação forçada $\left(55^{\circ} \mathrm{C}\right)$, por 72 horas e moídas em moinhos do tipo Wiley providos de peneiras de 2 e $1 \mathrm{~mm}$.

As amostras de oferecido, sobras e fezes foram analisadas para a determinação da MS, MO, N e EE, de acordo com o A.O.A.C. (1990); FDN com a técnica de "fiber bags" (Ankom®) utilizando metodologia descrita por Mertens (1998), usando-se de amilase e sulfito de sódio nas determinações. A FDA foi analisada de acordo com Van Soest et al. (1991), a lignina de acordo com Goering \& Van Soest (1970). 


\subsubsection{Coleta de conteúdo ruminal para determinação do $\mathbf{p H}$, ácidos graxos voláteis (AGV) e amônia}

As amostras de conteúdo ruminal foram coletadas no décimo terceiro e décimo quarto dia de cada período, com intervalos de duas horas entre as coletas. Os tempos de coletas foram representados pelos tempos zero, antes do fornecimento das dietas pela manhã, e 2, 4, 6, 8 e 10 horas após o fornecimento das dietas.

As amostras de conteúdo ruminal foram coletadas de quatro pontos distintos do rúmen, após prévia homogeneização do conteúdo no interior do rúmen e filtradas em quatro camadas de tecido de algodão (pano de fralda). Aproximadamente $200 \mathrm{~mL}$ de fluido ruminal filtrado foram utilizados para determinação imediata do $\mathrm{pH}$ de cada amostra. Esses valores foram determinados através de leitura direta em potenciômetro digital (Digimed TE-902).

Após a determinação do $\mathrm{pH}$ foram retiradas duas alíquotas de $25 \mathrm{~mL}$ do fluido ruminal, acrescentando-se 1,25 mL de solução $6 \mathrm{~N}$ de ácido clorídrico, conservando-as congeladas a $-10^{\circ} \mathrm{C}$, para posterior determinação de $\mathrm{NH}_{3}$ e $\mathrm{AGV}$.

Após o descongelamento, as amostras foram centrifugadas a $11.000 \mathrm{~g}$ a 4 ${ }^{\circ} \mathrm{C}$, durante 20 minutos, sendo uma fração do sobrenadante utilizada para a determinação de $\mathrm{N}-\mathrm{NH}_{3}$, de acordo com o método colorimétrico descrito por Chaney \& Marbach (1962) e adaptado para ser utilizado em placas de microtítulo e posterior leitura em aparelho do tipo "ELISA READER" com absorbância de 550 nanômetros, que apresenta resultados em $\mathrm{mg} / \mathrm{dL}$.

O restante do sobrenadante foi utilizado para a determinação dos AGV de acordo com Palmquist \& Conrad (1971b), utilizando cromatógrafo liquido gasoso, CLG (Hewlett Packard 5890, Series II), equipado com HP integrador (Hewlett Packard Company, Avondale, PA). O padrão interno foi o ácido 2-etilbutírico e o nitrogênio foi o gás de arraste. A temperatura do injetor, detector e coluna foram de 150,190 e $115^{\circ} \mathrm{C}$, respectivamente. 


\subsubsection{Análise estatística}

O experimento de digestibilidade foi conduzido num delineamento experimental em Quadrado Latino 4x4 (quatro animais x quatro períodos), adotando-se para análise estatística o procedimento GLM do programa estatístico SAS (1997). O quadro da análise da variância é mostrado no Quadro 2.

Causa de variação

Graus de liberdade

Animal

3

Período

3

Tratamento

Resíduo 6

Total 15

Quadro 2- Quadro esquemático de análise da variância para o ensaio de consumo e digestibilidade.

As variáveis $\mathrm{pH}, \mathrm{AGV}$ e $\mathrm{N}-\mathrm{NH}_{3}$ foram analisadas estatisticamente como parcelas subdivididas no tempo e analisadas estatisticamente pelo PROC MIXED, que define as variáveis fixas e aleatórias para execução da análise. Os efeitos de tratamento, animal e período foram testados com relação as parcelas. A interação horário de coleta $\mathrm{x}$ tratamento foi testada em relação as sub-parcelas. O quadro de análise da variância é mostrado no Quadro 3. Considerou-se 5\% ( $<<0,05)$ como nível de significância e até $10 \%$ como tendência $(\mathrm{P}<0,10)$ para a probabilidade do teste $\mathrm{F}$ na análise da variância. Para as variáveis que obtiveram respostas significativas, utilizou-se o comando LSMEANS para verificar as diferenças entre os tratamentos para as diversas variáveis. As médias das tabelas foram obtidas pelo comando LSMEANS para as parcelas e subparcelas. 


\begin{tabular}{lc}
\hline Causa de variação & Graus de liberdade \\
\hline Animal & 3 \\
Período & 3 \\
Tratamento & 3 \\
Resíduo A & 6 \\
\hline Parcelas & 15 \\
\hline Tempo & 11 \\
Tratamento & 3 \\
Tempo X tratamento & 33 \\
Resíduo B & 145 \\
\hline Subparcelas & 192 \\
\hline
\end{tabular}

Quadro 3- Quadro esquemático de análise da variância para pH, AGV e N-NH${ }_{3}$.

\subsection{Comportamento ingestivo}

Foram utilizados as mesmas instalações, animais, tratamentos e análise estatística do experimento de digestibilidade de nutrientes.

As observações foram realizadas a cada 15 dias, sendo necessário 10 dias de adaptação as dietas em cada período. Os animais foram observados individualmente e visualmente, por 24 horas, a intervalos de 5 minutos para determinar o tempo gasto em ingestão, ruminação e ócio. A atividade de mastigação foi calculada através do somatório das atividades de ingestão e ruminação, conforme Armentano \& Pereira (1997). As rações foram fornecidas ad libitum as 7:00 e 19:00 h. 


\section{RESULTADOS E DISCUSSÃO}

\subsection{Experimento I: Desempenho dos animais}

Os resultados do experimento de desempenho em termos de consumo de matériaseca, ganho de peso médio diário, conversão alimentar e peso vivo final são demonstrados nas Tabelas 6, 7, 8 e 9, respectivamente.

Tabela 6. Efeito dos tratamentos sobre o consumo de matéria seca $\left(\mathrm{kg} \cdot \mathrm{dia}^{-1}\right)$.

\begin{tabular}{|c|c|c|c|c|c|}
\hline \multicolumn{6}{|c|}{ Tratamentos } \\
\hline & \multicolumn{4}{|c|}{$\%$ de inclusão de BIN ${ }^{1}$} & Teste F \\
\hline & $5 \% \mathrm{BINmoa}^{2}$ & $5 \%$ BINdif $^{3}$ & $10 \%$ BINdif & $15 \%$ BINdif & $\mathrm{P}<0,05$ \\
\hline Sub-período 1 & $8,6 \pm 0,7 *$ & $8,2 \pm 0,7$ & $8,5 \pm 0,7$ & $7,9 \pm 0,7$ & 0,4158 \\
\hline Sub-período 2 & $9,5 \pm 0,6$ & $9,0 \pm 0,6$ & $10,1 \pm 0,6$ & $9,5 \pm 0,6$ & 0,0918 \\
\hline Sub-período 3 & $9,2 \pm 0,7^{(\mathrm{AB})}$ & $9,3 \pm 0,6^{(\mathrm{AB})}$ & $9,8 \pm 0,6^{(\mathrm{A})}$ & $8,1 \pm 0,6^{(\mathrm{B})}$ & 0,0069 \\
\hline Sub-período 4 & $9,6 \pm 0,9$ & $10,2 \pm 1,0$ & $10,2 \pm 0,9$ & $9,0 \pm 0,9$ & 0,2311 \\
\hline Média & $9,2 \pm 0,4^{(\mathrm{AB})}$ & $9,2 \pm 0,4^{(\mathrm{AB})}$ & $9,7 \pm 0,4^{(\mathrm{A})}$ & $8,7 \pm 0,4^{(\mathrm{B})}$ & 0,0060 \\
\hline
\end{tabular}

\% de inclusão do BIN em substituição ao BTPV

${ }^{2}$ Bagaço de cana-de-açúcar in natura - método convencional; ${ }^{3}$ Bagaço in natura - método difusão.

${ }^{(\mathrm{AB})}$ Médias seguidas de mesma letra não diferem estatisticamente pelo teste de Tukey.

* É o erro máximo da estimativa, ou seja, é a diferença entre a média e um dos limites do intervalo de confiança de $95 \%$.

O consumo de matéria-seca foi diferente $(\mathrm{P}<0,05)$ apenas no sub-período três e também na média geral, onde a dieta com maior nível de inclusão de BINdif (15\%) em substituição ao BTPV obteve consumo inferior a dieta com $10 \%$ de BINdif. 
Provavelmente a taxa de degradação e passagem mais lenta da dieta com maior quantidade de BINdif afetou o consumo dos animais, porém esse resultado não ocorreu nos demais sub-períodos, fato ocorrido pela seleção dos componentes da dieta pelos animais, recusando-se a ingerir o BINdif que era constantemente encontrado nas sobras dos animais, constatado pelos teores de FDN e FDA das análises das sobras. Os dados referentes ao consumo de matéria-seca são superiores aos encontrados por Hausknecht (1996) que utilizou dietas com e sem fonte de fibra íntegra (8\% BIN ou cana-de-açúcar), o autor encontrou valores de 6,81 e 7,57 kg MS/dia para o BIN e cana-de-açúcar, respectivamente.

Lanna \& Boin (1990) testando o feno de gramínea, BIN e BIN mais bicarbonato como fonte de fibra íntegra (8\% MS) em dietas com BTPV como principal volumoso, encontraram consumo superior $(\mathrm{P}<0,05)$ para as dietas com BIN mais bicarbonato em comparação apenas com a dieta com BIN e que as dietas com BIN não apresentaram diferenças no consumo em relação à dieta com feno de gramínea como fonte de fibra íntegra.

Lima \& Zanetti (1996) encontraram consumo de matéria-seca de $11,55 \mathrm{~kg}$ MS/dia para dietas sem fonte de fibra íntegra, utilizando o BTPV como volumoso principal e a relação volumoso: concentrado de 50:50. Resultado semelhante ao encontrado por Pate (1982) que foi de 10,42 kg MS/dia em dieta semelhante.

Esses dados demonstraram que a utilização de BINmoa e BINdif até o nível de inclusão de 10\% em substituição ao BTPV não prejudica o consumo de matéria-seca dos animais.

$\mathrm{O}$ ganho de peso médio diário não apresentou diferenças significativas $(\mathrm{P}<0,05)$ entre os tratamentos nos quatro sub-períodos (Tabela 7). Os dados são semelhantes aos encontrados por Hausknecht (1996) para dietas com BIN e cana-de-açúcar como fonte de fibra íntegra, 0,911 e 1,080 kg/dia, respectivamente, níveis considerados elevados já que os animais eram novos e 50\% eram fêmeas. Lanna \& Boin (1990) obtiveram ganho de peso superior para dietas com BIN mais bicarbonato em comparação ao BIN ou feno de gramínea como fontes de fibra íntegra, (1,019 contra 0,909 kg/dia). Lima \& Zanetti (1996) obtiveram médias de 1,041 a 1,258 kg/dia de ganho de peso em dietas com BTPV como principal volumoso sem fonte de fibra íntegra. Os resultados demonstram 
que o BINdif substituiu o BTPV de forma semelhante ao BINmoa sem prejudicar o desempenho dos animais até o nível de substituição mais elevado.

Tabela 7. Efeito dos tratamentos sobre o ganho de peso médio diário (kg.dia $\left.{ }^{-1}\right)$.

\begin{tabular}{|c|c|c|c|c|c|}
\hline & \multicolumn{5}{|c|}{ Tratamentos } \\
\hline & \multicolumn{4}{|c|}{$\%$ de inclusão de BIN ${ }^{1}$} & Teste F \\
\hline & $5 \% \mathrm{BINmoa}^{2}$ & $5 \%$ BINdif $^{3}$ & $10 \%$ BINdif & $15 \%$ BINdif & $\mathrm{P}<0,05$ \\
\hline Sub-período 1 & $1,06 \pm 0,12 *$ & $1,06 \pm 0,12$ & $0,99 \pm 0,13$ & $0,87 \pm 0,12$ & 0,1217 \\
\hline Sub-período 2 & $1,13 \pm 0,18$ & $1,18 \pm 0,17$ & $1,23 \pm 0,17$ & $1,12 \pm 0,17$ & 0,7907 \\
\hline Sub-período 3 & $0,88 \pm 0,09$ & $0,89 \pm 0,09$ & $0,88 \pm 0,09$ & $0,80 \pm 0,08$ & 0,3528 \\
\hline Sub-período 4 & $0,93 \pm 0,21$ & $1,13 \pm 0,21$ & $1,02 \pm 0,21$ & $0,80 \pm 0,21$ & 0,1842 \\
\hline Média & $1,00 \pm 0,1$ & $1,07 \pm 0,1$ & $1,03 \pm 0,1$ & $0,91 \pm 0,1$ & 0,1422 \\
\hline
\end{tabular}

$1 \%$ de inclusão do BIN em substituição ao BTPV

${ }^{2}$ Bagaço de cana-de-açúcar in natura - método convencional; ${ }^{3}$ Bagaço in natura - método difusão.

* É o erro máximo da estimativa, ou seja, é a diferença entre a média e um dos limites do intervalo de confiança de $95 \%$.

Tabela 8. Efeito dos tratamentos sobre a conversão alimentar (kg MS/kg ganho $\left.{ }^{-1}\right)$.

\begin{tabular}{|c|c|c|c|c|c|}
\hline \multicolumn{6}{|c|}{ Tratamentos } \\
\hline & \multicolumn{4}{|c|}{$\%$ de inclusão de BIN $^{1}$} & Teste F \\
\hline & $5 \% \mathrm{BINmoa}^{2}$ & $5 \%$ BINdif $^{3}$ & $10 \%$ BINdif & $15 \%$ BINdif & $\mathrm{P}<0,05$ \\
\hline Sub-período 1 & $8,3 \pm 0,7 *$ & $7,9 \pm 0,7$ & $8,6 \pm 0,7$ & $9,1 \pm 0,7$ & 0,1284 \\
\hline Sub-período 2 & $8,6 \pm 1,4$ & $7,6 \pm 1,4$ & $8,4 \pm 1,4$ & $8,5 \pm 1,4$ & 0,7311 \\
\hline Sub-período 3 & $12,1 \pm 2,2$ & $10,5 \pm 2,2$ & $11,7 \pm 2,2$ & $10,4 \pm 2,2$ & 0,5917 \\
\hline Sub-período 4 & $11,4 \pm 2,4$ & $9,8 \pm 2,5$ & $11,1 \pm 2,4$ & $11,1 \pm 2,5$ & 0,7500 \\
\hline Média & $10,1 \pm 1,0$ & $8,9 \pm 1,0$ & $9,9 \pm 1,0$ & $9,8 \pm 1,0$ & 0,3476 \\
\hline
\end{tabular}

A conversão alimentar que mede o consumo de matéria-seca para se ganhar um quilo de peso vivo não apresentou diferenças significativas $(\mathrm{P}>0,05)$ entre os 
tratamentos nos quatro sub-períodos (Tabela 8). Hausknecht (1996) encontrou valores de 9,27 e 7,58 para BIN e cana-de-açúcar, respectivamente. Os valores para o BIN se assemelham aos encontrados neste experimento. Já Lima \& Zanneti (1996) encontraram valor de 10,19 para dietas de BTPV sem fonte de fibra íntegra. Lanna \& Boin (1990) não encontraram diferenças $(\mathrm{P}>0,05)$ para a conversão alimentar de animais alimentados com BIN e feno de gramínea como fonte de fibra íntegra em dietas de BTPV.

O peso vivo final dos animais não apresentou diferenças significativas $(P>0,05)$ para os tratamentos (Tabela 9). Em trabalho de Lanna et al. (1998), verificou-se que dietas com níveis de $25 \%$ de concentrado na MS foram semelhantes, em termos de eficiência alimentar, a dietas com cerca de $45 \%$ de concentrado, embora o ganho de peso em dietas com $45 \%$ de concentrado tenha sido estatisticamente superior ao ganho no tratamento com $25 \%$ de concentrado, em todas as dietas utilizou-se $6 \%$ de BIN como fonte de fibra íntegra e BTPV como principal volumoso. Segundo Magalhães et al. (1999) o desempenho de animais alimentados com rações utilizando levedura (7\% na MS) melhorou, à medida que se diminuiu a porcentagem de BTPV na dieta, fato não observado neste experimento. Segundo o autor a alta solubilidade da levedura associada a tempo maior da fibra no rúmen contribuiu para melhores condições na fermentação, resultando em melhor desempenho. Em dietas com alto teor de concentrado, Bulle (2000) testou três níveis de BIN como fonte de fibra íntegra (9, 15 e 21\% na MS), sendo que o nível intermediário apresentou melhor peso vivo final quando comparado ao maior nível de inclusão $(448,7 \mathrm{~kg}$ vs 424,8 kg). 
Tabela 9. Efeito dos tratamentos sobre o peso vivo final $(\mathrm{kg})$.

\begin{tabular}{|c|c|c|c|c|c|}
\hline & \multicolumn{4}{|c|}{ Tratamentos } & \multirow{3}{*}{$\begin{array}{l}\text { Teste F } \\
\mathrm{P}<0,05\end{array}$} \\
\hline & \multicolumn{4}{|c|}{$\%$ de inclusão de BIN ${ }^{1}$} & \\
\hline & $5 \% \mathrm{BINmoa}^{2}$ & $5 \%$ BINdif $^{3}$ & $10 \%$ BINdif & $15 \%$ BINdif & \\
\hline Peso inicial & 274,8 & 281,8 & 279,1 & 285,8 & \\
\hline Sub-período 1 & $316,9 \pm 3,7 *$ & $317,0 \pm 3,7$ & $315,2 \pm 3,7$ & $311,4 \pm 3,7$ & 0,1271 \\
\hline Sub-período 2 & $345,9 \pm 4,7$ & $347,0 \pm 4,7$ & $348,3 \pm 4,7$ & $345,5 \pm 4,7$ & 0,8047 \\
\hline Sub-período 3 & $381,8 \pm 3,8$ & $380,8 \pm 3,8$ & $380,4 \pm 3,7$ & $377,2 \pm 3,7$ & 0,3120 \\
\hline $\begin{array}{c}\text { Sub-período } 4 \\
\text { (Peso final) }\end{array}$ & $403,5 \pm 5,4$ & $408,4 \pm 5,4$ & $405,6 \pm 5,3$ & $400,1 \pm 5,4$ & 0,1830 \\
\hline
\end{tabular}

\subsection{Experimento II: Digestibilidade de nutrientes}

\subsubsection{Composição das dietas}

Os valores da composição bromatológica das dietas encontram-se na Tabela 10 .

Tabela 10. Composição bromatológica das dietas (\% da MS).

\begin{tabular}{lcccc}
\hline \multicolumn{5}{c}{$\begin{array}{c}\text { Tratamentos } \\
\text { \% de inclusão de BIN }\end{array}$} \\
\hline Nutrientes (\% na MS) & $5 \%$ BINmoa $^{2}$ & $5 \%$ BINdif & $10 \%$ BINdif & 15\% BINdif \\
\hline MO $^{4}$ & 95,6 & 95,2 & 95,3 & 95,0 \\
$\mathrm{~PB}^{5}$ & 13,2 & 12,3 & 12,3 & 12,0 \\
$\mathrm{EE}^{6}$ & 0,93 & 1,02 & 0,84 & 0,92 \\
$\mathrm{FDN}^{7}$ & 37,7 & 41,6 & 44,0 & 45,4 \\
$\mathrm{FDA}^{8}$ & 27,5 & 29,0 & 30,6 & 29,5 \\
Lignina & 4,35 & 5,00 & 5,38 & 5,27 \\
\hline
\end{tabular}

1 Porcentagem de inclusão de BIN em substituição ao BTPV

2 Bagaço in natura - método convencional; 3 Bagaço in natura- método difusão

4 Matéria orgânica; 5 Proteína bruta; 6 Extrato etéreo

7 Fibra detergente neutro; 8 Fibra detergente ácido

As dietas apresentaram nível de proteína bruta semelhante, apesar da substituição do BIN pelo BTPV, caracterizando-as como isoproteícas, este fato é devido aos baixos 
níveis de PB tanto no BTPV como no BIN. O nível de FDN elevou-se nas dietas à medida que se efetuou a substituição do BTPV pelo BIN, pois o tratamento sob pressão e vapor sobre o bagaço in natura solubiliza a hemicelulose, reduzindo o seu teor a níveis insignificantes, dessa forma as dietas com menor proporção de BTPV apresentaram maiores teores de FDN.

Os valores de EE, FDA e lignina apresentaram resultados semelhantes, atestando uma composição bromatológica de acordo com o principal objetivo do trabalho, testar o efeito do bagaço de cana-de-açúcar in natura obtido pelo método convencional e pelo método de difusão como fonte de fibra íntegra em dietas para bovinos de corte com o BTPV como principal volumoso.

\subsubsection{Efeito dos tratamentos sobre o consumo de matéria seca e digestibilidade aparente dos nutrientes no trato digestivo total.}

A utilização do BIN obtido pelo método de difusão em níveis mais elevados não apresentou efeito significativo $(\mathrm{P}>0,05)$ sobre a digestibilidade da matéria seca, matéria orgânica, proteína bruta, FDN, FDA e EE quando comparado com o BIN obtido pelo método convencional de moagem. Porém, reduziu $(\mathrm{P}<0,05)$ o consumo de matéria seca, matéria orgânica, proteína bruta, FDN e a digestibilidade em quilogramas da MS e MO quando comparado com o BIN obtido pelo método convencional de moagem. Houve tendência $(\mathrm{P}<0,09)$ na redução do consumo de FDA quando da utilização do nível mais elevado de BIN obtido por difusão (Tabelas 11, 12 e 13).

Tabela 11. Efeito dos tratamentos sobre o consumo e a digestibilidade aparente no trato digestivo total da matéria seca e da matéria orgânica. 


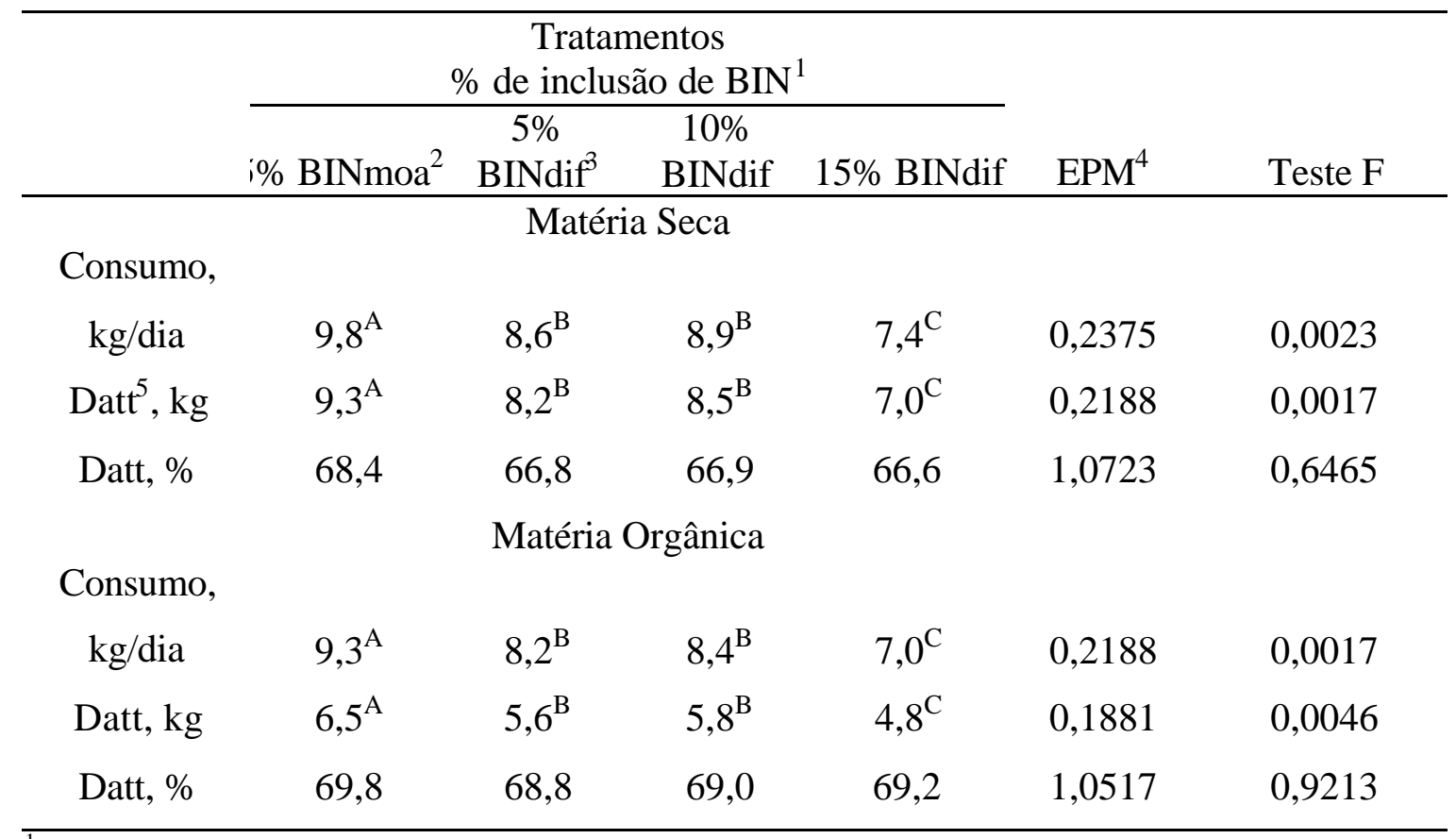

${ }^{1}$ Porcentagem de inclusão de BIN em substituição ao BTPV

${ }^{2}$ Bagaço in natura- método convencional; ${ }^{3}$ Bagaço in natura- método difusão

${ }_{5}^{4}$ Erro padrão da média

${ }^{5}$ Digestibilidade aparente no trato digestivo total.

${ }^{\mathrm{A}, \mathrm{B}}$ Médias seguidas da mesma letra na linha não diferem entre si a $(\mathrm{P}>0,05)$.

A introdução de bagaço de cana-de-açúcar in natura limitou a ingestão voluntária das rações, dados estes que estão de acordo com Ezequiel \& Andrade (1988). Os mesmos autores descrevem que a utilização do bagaço de cana-de-açúcar afeta negativamente a utilização da fibra bruta e da matéria-seca das rações. Entretanto, os dados observados no presente trabalho diferem dos resultados de Hausknecht (1996) que forneceu dietas com e sem fonte de fibra íntegra (8\% de BIN ou cana-de-açúcar) em dietas com 50\% de concentrado e o BTPV como principal volumoso. O autor encontrou maior consumo de matéria-seca para as dietas com fonte de fibra íntegra, o que pode ser explicado por um menor consumo nas dietas sem fonte de fibra devido às condições ruminais inadequadas encontradas pelo autor, inibindo o consumo voluntário de matéria seca.

$\mathrm{O}$ mesmo autor não encontrou diferenças significativas $(\mathrm{P}>0,05)$ para as digestibilidades da MS, MO, FDN, FDA e EE. Para as dietas com $8 \%$ de BIN como 
fonte de fibra íntegra, o autor encontrou valores um pouco abaixo $(60,5 \%$ e $60,3 \%)$ de digestibilidade da matéria-seca dos dados obtidos neste trabalho.

Tabela 12. Efeito dos tratamentos sobre o consumo e a digestibilidade aparente no trato digestivo total da fibra em detergente neutro e da fibra em detergente ácido.

Tratamentos

\begin{tabular}{|c|c|c|c|c|c|c|}
\hline & \multicolumn{4}{|c|}{$\begin{array}{c}\text { Tratamentos } \\
\% \text { de inclusão de BIN }{ }^{1}\end{array}$} & \multirow[b]{2}{*}{$\mathrm{EPM}^{4}$} & \multirow[b]{2}{*}{ Teste F } \\
\hline & $\begin{array}{c}5 \% \\
\text { BINmoa }^{2}\end{array}$ & $\begin{array}{c}5 \% \\
\text { BINdif }^{3}\end{array}$ & $\begin{array}{l}10 \% \\
\text { BINdif }\end{array}$ & $\begin{array}{l}15 \% \\
\text { BINdif }\end{array}$ & & \\
\hline \multicolumn{7}{|c|}{ Fibra em Detergente Neutro } \\
\hline Consumo, $\mathrm{kg} / \mathrm{dia}$ & $3,7^{\mathrm{A}}$ & $3,6^{\mathrm{A}}$ & $3,8^{\mathrm{A}}$ & $3,1^{\mathrm{B}}$ & 0,126 & 0,0388 \\
\hline $\operatorname{Datt}^{5}, \mathrm{~kg}$ & 1,9 & 2,0 & 2,1 & 1,7 & 0,137 & 0,3291 \\
\hline Datt, \% & 53,6 & 55,1 & 54,9 & 54,2 & 2,157 & 0,9256 \\
\hline \multicolumn{7}{|c|}{ Fibra em Detergente Ácido } \\
\hline Consumo, kg/dia & 2,7 & 2,5 & 3,0 & 2,0 & 0,221 & 0,0804 \\
\hline Datt, kg & 1,4 & 1,2 & 1,7 & 0,9 & 0,219 & 0,1692 \\
\hline Datt, \% & 51,3 & 49,2 & 54,8 & 45,1 & 3,468 & 0,3378 \\
\hline
\end{tabular}

${ }^{1}$ Porcentagem de inclusão de BIN em substituição ao BTPV

2 Bagaço in natura- método convencional; ${ }^{3}$ Bagaço in natura- método difusão

${ }^{4}$ Erro padrão da média

${ }^{5}$ Digestibilidade aparente no trato digestivo total

${ }^{A, B}$ Médias seguidas da mesma letra na linha não diferem entre si a $(\mathrm{P}>0,05)$.

As digestibilidades de FDN e FDA apresentaram resultados semelhantes e não diferiram entre os tratamentos $(\mathrm{P}>0,05)$, esses dados estão de acordo com Hausknecht (1996). Segundo o autor, apesar da tendência em outros volumosos de apresentarem diferenças na digestibilidade de FDN e FDA, pois o primeiro apresenta a porção mais digerível da parede celular, no caso de dietas com BTPV esta afirmação não é verdadeira, pois a fração hemicelulose do bagaço de cana-de-açúcar é praticamente toda transformada em açúcares durante o tratamento sob pressão e vapor e, portanto, no caso do BTPV, tanto a FDN quanto a FDA representam aproximadamente os mesmos componentes. $\mathrm{O}$ autor encontrou valores em torno de $44 \%$ e $45 \%$ de digestibilidade de FDN e FDA, respectivamente para as dietas com $8 \%$ de BIN como fonte de fibra íntegra, valores inferiores aos encontrados no presente trabalho (Tabela 12). 
O mesmo autor não encontrou diferenças na digestibilidade dos componentes fibrosos (FDN e FDA) entre os tratamentos com e sem fonte de fibra íntegra, segundo o autor este fato pode ter ocorrido pelo tipo de fibra incluído na dieta (BIN ou cana-deaçúcar) serem de baixa qualidade e terem baixas taxas de degradação.

$\mathrm{O}$ consumo de proteína bruta apresentou diferenças $(\mathrm{P}<0,05)$ entre os tratamentos (Tabela 13), provavelmente em virtude do baixo consumo de matéria-seca e da concentração de PB na dieta com maior inclusão de BIN obtido pelo método de difusão.

A digestibilidade aparente da PB variou de 66,9 a $71,1 \%$, não ocorrendo diferenças $(\mathrm{P}>0,05)$ entre os tratamentos (Tabela 13). Esses dados estão próximos do valor encontrado por Hausknecht (1996), que foi de $66,1 \%$ de digestibilidade. De acordo com Lanna \& Boin (1990) a ocorrência de compostos fenólicos no BTPV tem sido apresentada como um dos fatores responsáveis pela baixa digestibilidade da PB e que a produção de proteína microbiana no intestino grosso devido à disponibilidade de substrato resultante da alta passagem de dietas à base de BTPV, poderia também ser responsável em parte pela baixa digestibilidade da PB dessas dietas. Concordando, Bulle (2000) cita que a exigência de proteína metabolizável (aminoácidos absorvidos no intestino) em dietas com BTPV pode ser alterada pelos compostos fenólicos produzidos durante a hidrólise, já que estes compostos inibem a digestão e absorção da proteína no intestino.

Os resultados da digestibilidade de matéria-seca e nutrientes no trato digestivo total demonstrados ratificam os resultados de desempenho que não apresentaram diferenças significativas $(\mathrm{P}>0,05)$ nas variáveis estudadas, possibilitando afirmar que a utilização de BINdif não prejudicou o desempenho e a digestibilidade da matéria-seca e nutrientes no trato digestivo total se comparado a utilização de BINmoa e que até o nível de substituição utilizado para o BTPV pelo BINdif não ocorreu queda do desempenho dos animais.

Tabela 13. Efeito dos tratamentos sobre o consumo e a digestibilidade aparente da proteína bruta e extrato etéreo no trato digestivo total. 


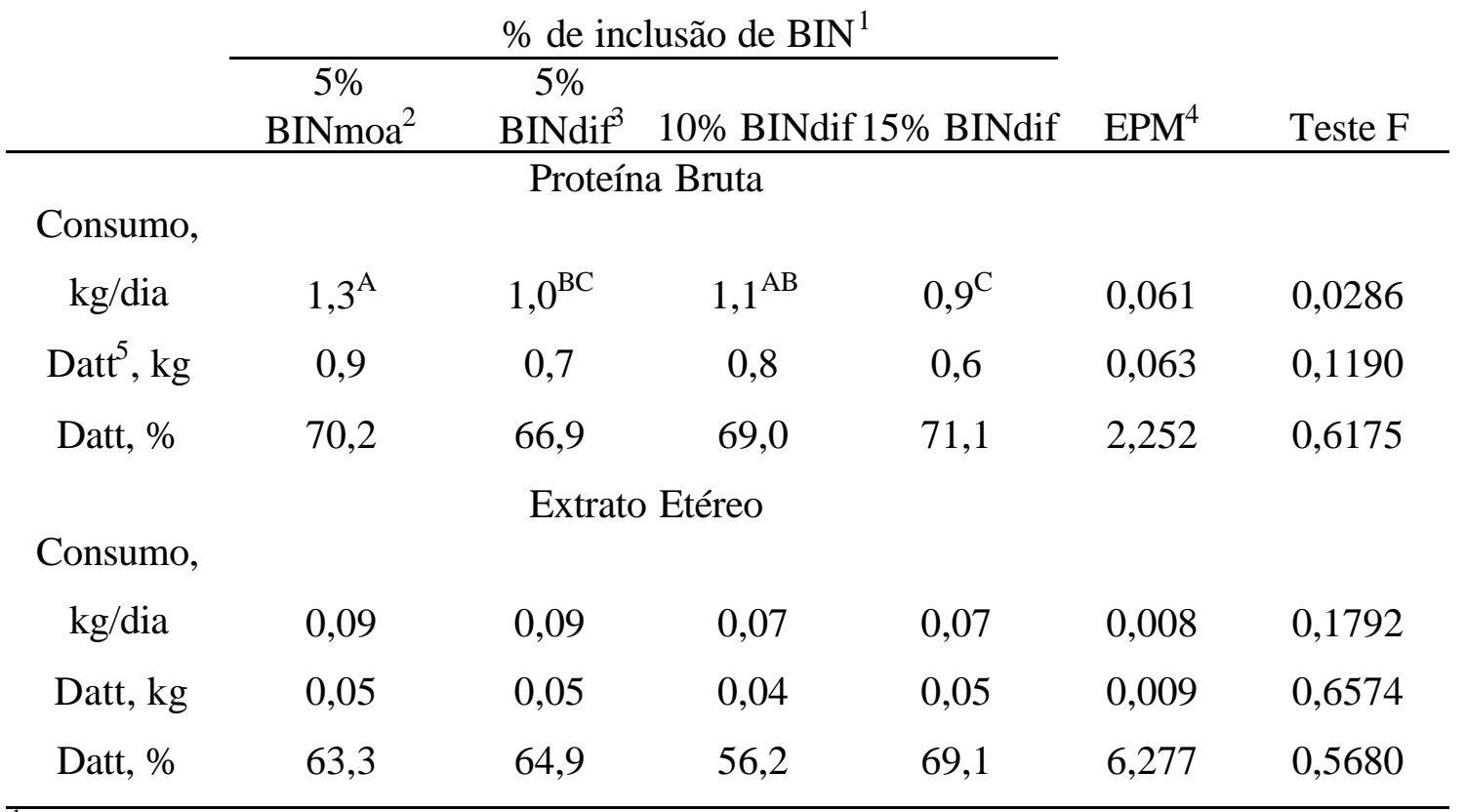

${ }^{1}$ Porcentagem de inclusão de BIN em substituição ao BTPV

${ }^{2}$ Bagaço in natura- método convencional; ${ }^{3}$ Bagaço in natura- método difusão

${ }^{4}$ Erro padrão da média

${ }^{5}$ Digestibilidade aparente no trato digestivo total.

${ }^{\mathrm{A}, \mathrm{B}}$ Médias seguidas da mesma letra na linha não diferem entre si a $(\mathrm{P}>0,05)$.

\subsection{Parâmetros ruminais}

\subsection{1 pH ruminal}

O efeito da substituição do BTPV pelo BIN sobre o pH ruminal está representado na Tabela 14.

Tabela 14. Efeito da substituição do BTPV pelo BIN sobre o pH ruminal.

Tratamentos

$\%$ de inclusão de BIN ${ }^{1}$ 


\begin{tabular}{llllll}
\hline 0 & 6,80 & 6,87 & 6,98 & 7,03 & $6,92^{\mathrm{A}}$ \\
2 & 6,63 & 6,61 & 6,75 & 6,85 & $6,71^{\mathrm{B}}$ \\
4 & 6,49 & 6,50 & 6,55 & 6,74 & $6,57^{\mathrm{CD}}$ \\
6 & 6,44 & 6,40 & 6,41 & 6,60 & $6,46^{\mathrm{E}}$ \\
8 & 6,50 & 6,39 & 6,48 & 6,55 & $6,48^{\mathrm{DE}}$ \\
10 & 6,52 & 6,62 & 6,61 & 6,73 & $6,62^{\mathrm{BC}}$ \\
Parcelas $^{4}$ & 6,56 & 6,57 & 6,63 & 6,75 & \\
\hline
\end{tabular}

${ }^{1}$ Porcentagem de inclusão de BIN em substituição ao BTPV.

${ }^{2}$ Horas após o fornecimento da ração pela manhã.

${ }^{3}$ Média das subparcelas (tempo).

${ }^{4}$ Média das parcelas (tratamentos).

${ }^{\mathrm{ABC}}$ Médias seguidas de letras iguais, na mesma coluna, não diferem entre si $(\mathrm{P}>0,05)$.

Não houve diferença $(\mathrm{P}>0,05)$ nos valores médios diários de $\mathrm{pH}$ ruminal de cada tratamento (parcelas) e na interação tratamento x tempo. No entanto, houve diferença $(\mathrm{P}<0,05)$ no decorrer do dia (subparcelas), caracterizando a curva padrão de fermentação ruminal (Figura 1). Por outro lado, Hausknecht (1996) obteve valores de $\mathrm{pH}$ abaixo dos desejados durante a maior parte do dia mesmo utilizando $8 \%$ de cana de açúcar como fonte de fibra íntegra em dietas com BTPV, como principal volumoso, e 50\% de concentrado, porém os tratamentos com fonte de fibra íntegra apresentaram um valor médio de $\mathrm{pH}$ mais adequado $(6,07)$ do que o tratamento sem fonte de fibra íntegra $(5,81)$.

Já Castro (1989) descreveu que a substituição de BIN por BTPV provocou acentuado abaixamento no $\mathrm{pH}$ ruminal $(5,89)$, muito embora o autor não tenha utilizado nenhum tamponante ou ionóforo. Por outro lado, Francisco Jr. (1994) observou pequena elevação do pH ruminal $(5,91 ; 6,17$ e 6,04) adicionando-se níveis crescentes de lasalocida sódica $(0 \mathrm{~g} ; 0,21 \mathrm{~g}$ e $0,42 \mathrm{~g})$ em dietas com BTPV como único volumoso. Segundo o autor, os valores de $\mathrm{pH}$ abaixo de 6,2 durante a maior parte do dia prejudicam o crescimento de bactérias digestoras de fibra.

Silva (1990) encontrou valores de $\mathrm{pH}$ entre 6,2 e 6,8 ao longo do dia utilizando o BTPV como volumoso, os quais se assemelham aos encontrados no presente trabalho. No entanto, o autor utilizou-se de $\mathrm{NaHCO}_{3}$, lasalocida sódica e calcário calcítico tipo "filler" como fonte de cálcio das dietas, o que contribuiu para manter os níveis de $\mathrm{pH}$ dentro de valores considerados satisfatórios. 
De acordo com Owens \& Goetsch (1988), entre meia e quatro horas logo após a alimentação o pH ruminal alcança os valores mais baixos, refletindo o balanço entre a taxa de produção de ácidos, a entrada de tamponantes da saliva e a participação de tamponantes presentes no alimento. Segundo os autores o pH varia entre 5,5 e 6,2 em uma dieta com maior teor de concentrado, enquanto que dietas com maior participação de volumosos, valores entre 6,2 e 7,0 são esperados.

Os dados de $\mathrm{pH}$ sugerem que os tratamentos apresentaram um padrão de fermentação ruminal adequado a ação de bactérias celulolíticas, mesmo utilizando-se de $50 \%$ de concentrado e BTPV como principal volumoso sem a adição de tamponantes e ionóforos, que em vários estudos proporcionou valores de $\mathrm{pH}$ abaixo dos níveis mínimos recomendados, gerando prejuízo ao padrão de fermentação ruminal e a saúde dos animais.

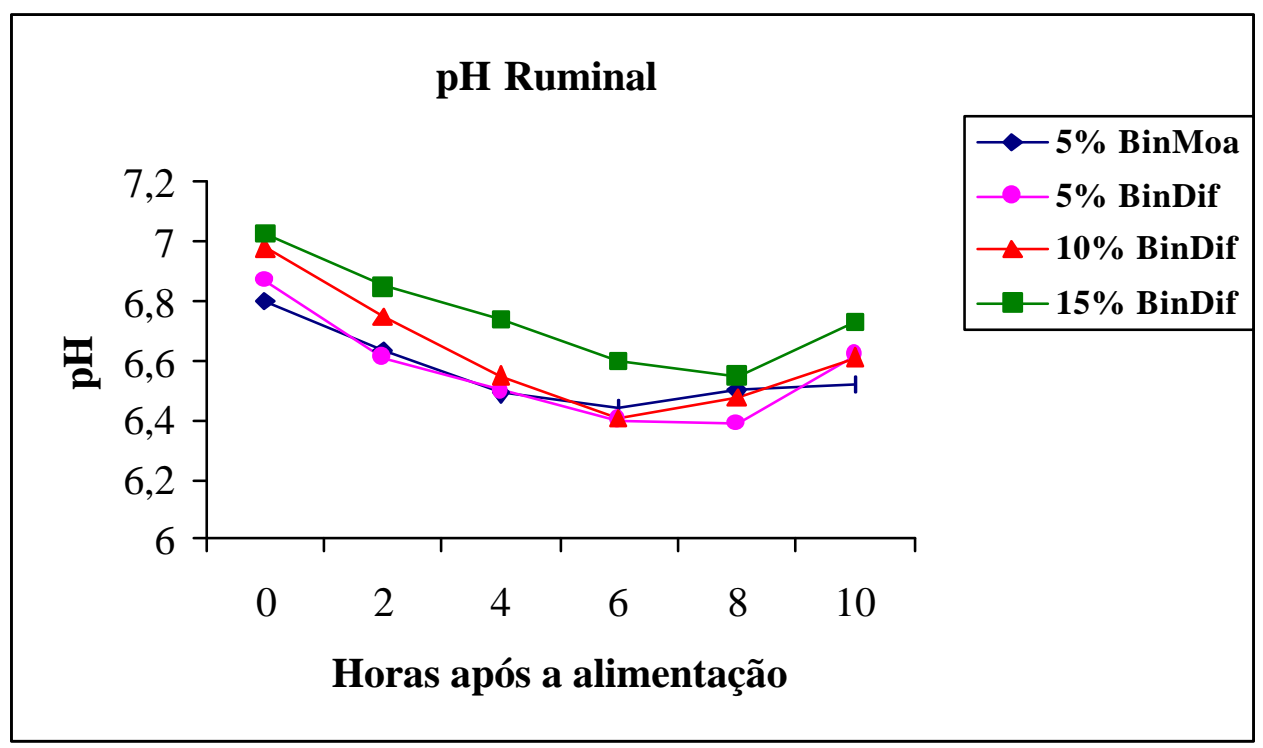

Figura 1- Efeitos dos tratamentos sobre a variação diurna do pH no fluido ruminal.

A inclusão de níveis crescentes de BIN como fonte de fibra íntegra proporcionou um maior estímulo à ruminação (Tabela 21), provocando uma maior produção de saliva e consequiente liberação de tamponantes naturais, neutralizando os efeitos negativos do BTPV sobre o $\mathrm{pH}$ ruminal. 


\subsubsection{Concentração de nitrogênio amoniacal $\left(\mathrm{N}-\mathrm{NH}_{3}\right)$ no rúmen}

$\mathrm{O}$ efeito da substituição de BIN por BTPV na concentração de $\mathrm{N}_{-} \mathrm{NH}_{3}$ está representado na Tabela 15. A Figura 2 ilustra o comportamento da concentração de $\mathrm{N}$ no fluido ruminal, alcançando seu valor máximo duas horas após o fornecimento das dietas pela manhã.

Não foi encontrada diferença significativa $(\mathrm{P}>0,05)$ na concentração de $\mathrm{N}_{-} \mathrm{NH}_{3}$ entre os valores médios diários de cada tratamento (parcelas) nem na interação tempo $\mathrm{x}$ tratamento, porém houve diferença $(\mathrm{P}<0,05)$ ao longo do dia (subparcelas). Da mesma forma, Hausknecht (1996) trabalhando com dietas a base de BTPV com ou sem fonte de fibra íntegra (8\% de cana-de-açúcar) não observou diferenças nos tratamentos, de acordo com o autor houve um incremento na concentração de amônia atingindo-se valores máximos duas horas após o fornecimento dos alimentos.

Ao observarmos a Tabela 15 nota-se que a maioria dos valores estão acima de 10 mg/dL de fluido ruminal, que é o valor mínimo recomendado por Francisco Jr. (1994) para a máxima degradação do BTPV.

Segundo Merchen (1988) quantidades significativas de amônia são produzidas no

rúmen pela degradação microbiana da proteína da dieta, hidrólise do nitrogênio não protéico proveniente da dieta e por via endógena e da passagem e degradação de células microbianas. A amônia produzida pode então ser utilizada como fonte de $\mathrm{N}$ para a biossíntese de aminoácidos pelos microorganismos ruminais ou ser absorvida pela parede do rúmen por difusão passiva. A quantidade absorvida é relacionada positivamente com a concentração de amônia e pH ruminal. Como as dietas eram isoproteícas e isoenergéticas era de se esperar que não houvesse diferenças entre os tratamentos, sendo que a concentração de amônia ruminal seguiu um padrão de fermentação ruminal típico.

Tabela 15. Efeito dos tratamentos sobre a concentração de $\mathrm{N}-\mathrm{NH}_{3}$ ruminal $(\mathrm{mg} / \mathrm{dL})$

Tratamentos

$\%$ de inclusão de BIN $^{1}$

Subparcelas $^{3}$ 


\begin{tabular}{lccccc} 
Tempos $^{2}$ & 5\% BinMoa & 5\% BinDif & 10\% BinDif & $15 \%$ BinDif & P $<0,05$ \\
\hline 0 & 12,4 & 11,9 & 13,2 & 11,9 & $12,39^{\mathrm{CD}}$ \\
2 & 21,5 & 21,9 & 21,9 & 20,3 & $21,44^{\mathrm{A}}$ \\
4 & 17,2 & 17,7 & 20,0 & 22,3 & $19,35^{\mathrm{B}}$ \\
6 & 14,6 & 13,7 & 12,6 & 16,5 & $14,38^{\mathrm{C}}$ \\
8 & 12,3 & 11,6 & 9,12 & 12,0 & $11,27^{\mathrm{D}}$ \\
10 & 10,4 & 10,2 & 9,00 & 13,8 & $10,87^{\mathrm{D}}$ \\
Parcelas $^{4}$ & 14,7 & 14,5 & 14,3 & 16,1 & \\
\hline
\end{tabular}

${ }^{1}$ Porcentagem de inclusão de BIN em substituição ao BTPV.

${ }^{2}$ Horas após o fornecimento da ração pela manhã.

${ }^{3}$ Média das subparcelas (tempo).

${ }^{4}$ Média das parcelas (tratamentos).

${ }^{\mathrm{ABC}}$ Médias seguidas de letras iguais, na mesma coluna, não diferem entre si $(\mathrm{P}>0,05)$.

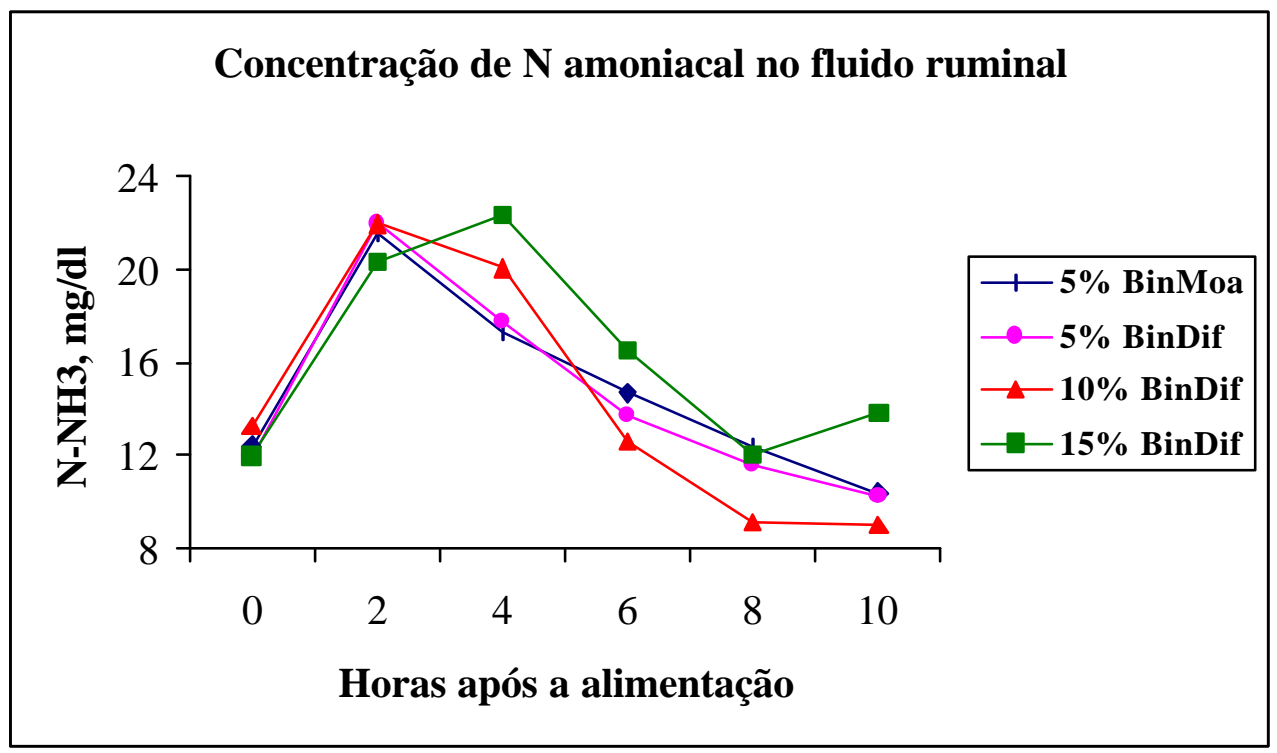

Figura 2- Efeito dos tratamentos sobre a concentração ruminal de nitrogênio amoniacal

\subsubsection{Concentração Ruminal de Ácidos Graxos Voláteis (AGV)}




\subsubsection{1 Ácidos Graxos Voláteis Totais}

Os valores médios da concentração molar dos ácidos graxos voláteis totais encontram-se na Tabela 16. A Figura 3 demonstra o comportamento da concentração de $\mathrm{AGV}$ no fluido ruminal, alcançando às duas horas após a alimentação da manhã seu valor máximo.

Tabela 16. Efeito dos tratamentos sobre a concentração total de AGV no fluido ruminal $(\mathrm{mM} / \mathrm{L})$.

\begin{tabular}{|c|c|c|c|c|c|}
\hline & & & tamentos & & \\
\hline & & $\%$ de incl & são de BIN ${ }^{1}$ & & Subparcelas $^{3}$ \\
\hline Tempos $^{2}$ & $5 \%$ BinMoa & $5 \%$ BinDif & $10 \%$ BinDif & $15 \%$ BinDif & $\mathrm{P}<0,05$ \\
\hline 0 & 133,2 & 131,6 & 108,8 & 116,2 & $122,50^{C}$ \\
\hline 2 & 161,6 & 148,1 & 141,4 & 140,8 & $148,00^{\mathrm{A}}$ \\
\hline 4 & 152,9 & 147,7 & 139,3 & 136,3 & $144,13^{\mathrm{AB}}$ \\
\hline 6 & 157,5 & 141,0 & 143,3 & 138,4 & $145,10^{\mathrm{AB}}$ \\
\hline 8 & 146,1 & 147,8 & 148,1 & 142,1 & $146,08^{\mathrm{AB}}$ \\
\hline 10 & 141,1 & 139,6 & 135,3 & 139,5 & $138,91^{\mathrm{B}}$ \\
\hline Parcelas & 148,7 & 142,6 & 136,0 & 135,6 & \\
\hline $\begin{array}{l}{ }^{1} \text { Porcentag } \\
{ }^{2} \text { Horas apó } \\
{ }^{3} \text { Média das } \\
{ }^{4} \text { Média das }\end{array}$ & $\begin{array}{l}\text { de inclusão de } \\
\text { fornecimento d } \\
\text { bparcelas (temp } \\
\text { arcelas (tratamer }\end{array}$ & $\begin{array}{l}\text { IN em substitui } \\
\text { ração pela man } \\
\text {. }\end{array}$ & ão ao BTPV. & & \\
\hline
\end{tabular}

Não houve diferença $(\mathrm{P}>0,05)$ na concentração de ácidos graxos voláteis totais entre os valores médios diários de cada tratamento (parcelas) nem na interação tratamento $\mathrm{x}$ tempo, ocorrendo diferença apenas $(\mathrm{P}<0,05)$ no decorrer do dia (subparcelas).

Também Hausknecht (1996), não detectou diferenças significativas na produção total de AGV, em dietas a base de BTPV com e sem fonte de fibra íntegra (8\% de cana-deaçúcar). Segundo o autor, a maior produção de ácido propiônico foi compensada pela queda na produção de ácido acético.

Uma maior concentração total de AGV foi encontrada em dieta com BTPV em relação à dieta com BIN como volumosos exclusivos por Castro (1989). De acordo com o 
autor, as diferenças encontradas na concentração total de AGV são explicadas pelo maior teor de carboidratos solúveis do BTPV.

Segundo Ribeiro (1999) a fermentação dos alimentos pelos microorganismos ruminais, além de liberar energia e compostos nitrogenados para seu próprio crescimento, produz também ácidos graxos voláteis totais, os quais são a principal fonte de energia para o animal hospedeiro.

Embora alguma quantidade de ácidos graxos voláteis deixe o rúmen com a digesta ocorrendo sua absorção no omaso e abomaso, a maior totalidade dos ácidos produzidos pela fermentação ruminal são absorvidos diretamente no rúmen (Merchen, 1988). De acordo com Church (1988) a quantidade de ácidos graxos voláteis no fluido ruminal é reflexo da atividade microbiana e da taxa de absorção destes pela parede ruminal e esta proporção varia com o tipo de substrato, nível de ingestão, freqüência de alimentação, taxa de diluição e osmolaridade.

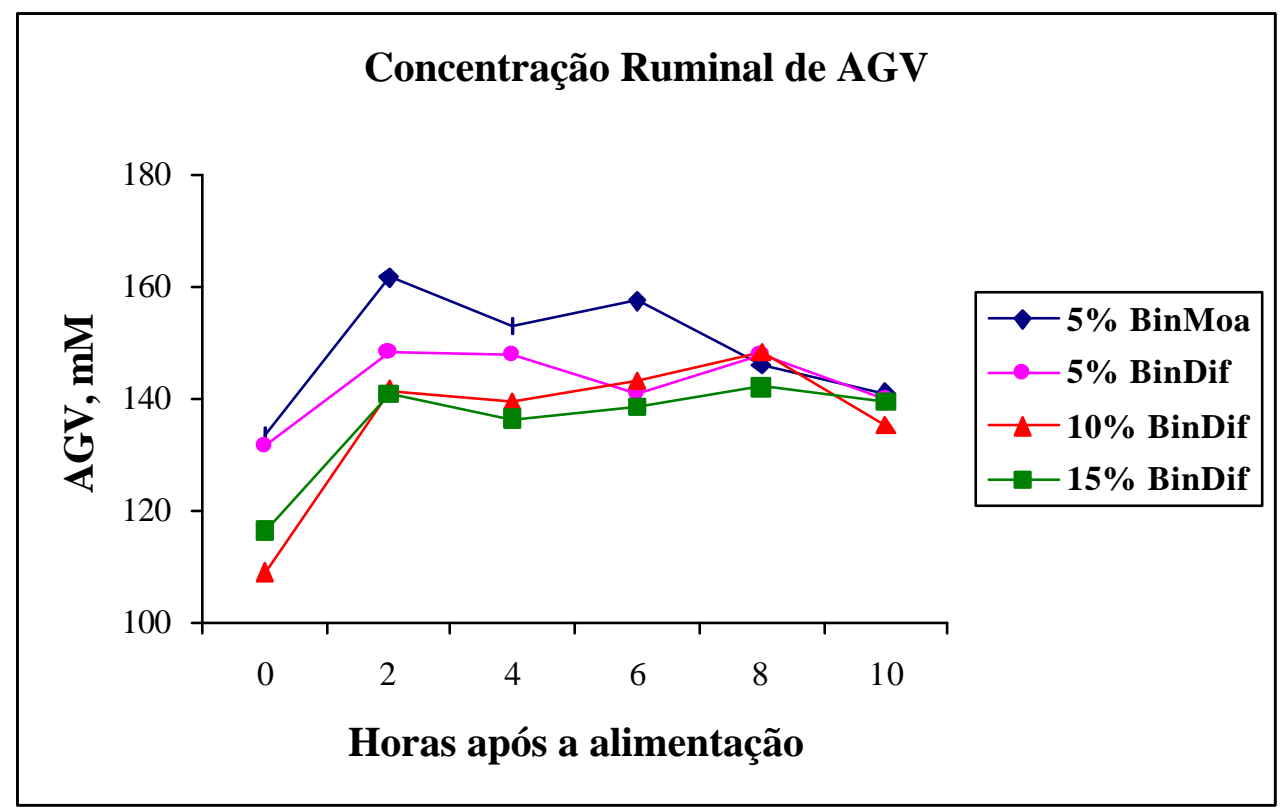

Figura 3- Efeitos dos tratamentos sobre a concentração ruminal dos ácidos graxos voláteis totais $(\mathrm{mM})$.

Apesar da redução progressiva de BTPV nos tratamentos com a inclusão de BIN nas dietas, não houve alterações significativas na concentração total de ácidos graxos 
voláteis, indicando que a utilização do BIN proveniente de difusores como fonte de fibra íntegra, pode ser utilizado como substituto parcial do BTPV nos níveis de BIN testados sem prejudicar a concentração total de AGV.

\subsubsection{2 Ácido acético}

Tabela 17. Efeito dos tratamentos sobre a concentração de acetato no fluido ruminal $(\mathrm{mM} / \mathrm{L})$

\begin{tabular}{lccccc}
\hline \multicolumn{5}{c}{ Tratamentos } \\
\hline Tempos $^{2}$ & 5\% BinMoa & 5\% BinDif & 10\% BinDif & 15\% BinDif & Subparcelas $^{3}$ \\
\hline 0 & 82,3 & 80,8 & 72,6 & 74,1 & P $<0,05$ \\
2 & 100,9 & 91,7 & 89,7 & 91,7 & $77,51^{\mathrm{C}}$ \\
4 & 95,7 & 92,0 & 88,6 & 88,2 & $93,56^{\mathrm{A}}$ \\
6 & 97,7 & 88,7 & 87,7 & 88,0 & $91,15^{\mathrm{A}}$ \\
8 & 90,3 & 90,9 & 91,4 & 90,4 & $90,57^{\mathrm{AB}}$ \\
10 & 86,4 & 85,4 & 82,8 & 87,8 & $80,79^{\mathrm{A}}$ \\
Parcelas $^{4}$ & 92,2 & 88,3 & 85,5 & 86,7 & $855^{\mathrm{B}}$ \\
\hline
\end{tabular}

Porcentagem de inclusão de BIN em substituição ao BTPV.

${ }^{2}$ Horas após o fornecimento da ração pela manhã.

${ }^{3}$ Média das subparcelas (tempo).

${ }^{4}$ Média das parcelas (tratamentos).

${ }^{\mathrm{ABC}}$ Médias seguidas de letras iguais, na mesma coluna, não diferem entre si ( $\left.\mathrm{P}>0,05\right)$.

O efeito dos tratamentos sobre a concentração de acetato no fluido ruminal está demonstrado na Tabela 17. A Figura 4 ilustra o comportamento da concentração de acetato no fluido ruminal, que manteve valores máximos entre duas e oito horas após a alimentação.

Não houve diferença $(\mathrm{P}>0,05)$ na concentração de acetato entre os valores médios diários de cada tratamento (parcelas) nem na interação tratamento x tempo, no entanto houve diferença $(\mathrm{P}<0,05)$ no decorrer do dia (subparcelas). Hausknecht (1996) obteve um efeito significativo $(\mathrm{P}<0,05)$ da presença de fibra íntegra ( $8 \%$ de cana-de-açúcar) nas dietas experimentais sobre a porcentagem molar de ácido acético. Segundo o autor, o aumento da proporção de ácido acético, observado nas dietas com fibra íntegra, pode ser 
explicado pelo maior $\mathrm{pH}$ observado nestas dietas, que favoreceu a atividade de bactérias celulolíticas.

Castro (1989) trabalhando com BIN e BTPV como volumosos exclusivos encontrou menor porcentagem de ácido acético na dieta com BTPV. De acordo com Ribeiro (1999) a concentração de ácido acético no fluido ruminal é dependente da relação entre os carboidratos estruturais e não estruturais da dieta e a quantidade de carboidratos fermentáveis no rúmen.

A manutenção de valores de $\mathrm{pH}$ acima de 6,0 devido a inclusão de BIN deve ter contribuído para se manter estabilizada a ação das bactérias celulolíticas, dessa forma os valores de ácido acético permaneceram num platô durante a maior parte do dia indicando um bom aproveitamento da porção fibra das dietas.

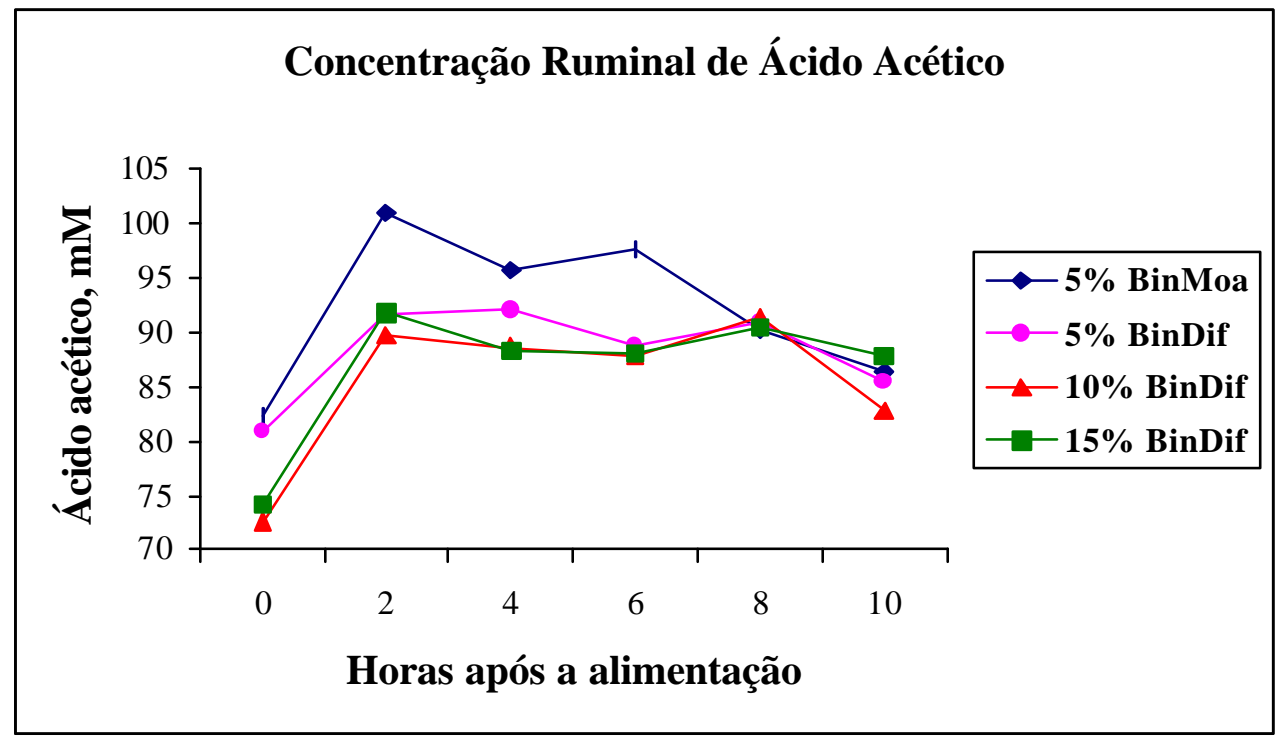

Figura 4- Efeito dos tratamentos sobre a concentração ruminal de ácido acético (mM).

\subsubsection{3 Ácido propiônico}

O efeito dos tratamentos na concentração molar de propionato no fluido ruminal está representado na Tabela 18. Não houve efeito da inclusão crescente de BIN (P>0,05) sobre os valores médios diários da concentração de propionato entre os tratamentos 
(parcelas) nem na interação tempo $\mathrm{x}$ tratamento, porém houve diferença $(\mathrm{P}<0,05)$ ao longo do dia (subparcelas) como demonstrado na Figura 5. As dietas contendo BTPV sem fibra íntegra produziram maiores proporções de ácido propiônico que as dietas com fonte de fibra íntegra em trabalho de Hausknecht (1996). Esses dados estão de acordo com Castro (1989) que encontrou maior produção de ácido propiônico na dieta com BTPV como volumoso exclusivo, ainda que a relação volumoso/concentrado tenha sido maior que a da dieta com BIN como volumoso exclusivo. Segundo o autor este dado indica que a hemicelulose transformada em carboidratos solúveis deve estar sendo degradada no rúmen produzindo principalmente ácido propiônico.

A absorção de glicose do trato intestinal de ruminantes é insignificante, sendo o propionato o precursor mais importante para a formação de glicose no ruminantes (Simas, 1997).

Tabela 18. Efeito dos tratamentos sobre a concentração de propionato no fluido ruminal $(\mathrm{mM} / \mathrm{L})$.

\begin{tabular}{|c|c|c|c|c|c|}
\hline \multicolumn{6}{|c|}{ Tratamentos } \\
\hline \multicolumn{5}{|c|}{$\%$ de inclusão de BIN ${ }^{1}$} & \multirow{2}{*}{$\frac{\text { Subparcelas }^{3}}{\mathrm{P}<0,05}$} \\
\hline Tempos $^{2}$ & $5 \%$ BinMoa & $5 \%$ BinDif & $10 \%$ BinDif & $15 \%$ BinDif & \\
\hline 0 & 29,9 & 31,3 & 25,2 & 23,3 & $27,45^{\mathrm{B}}$ \\
\hline 2 & 38,4 & 35,1 & 31,4 & 30,2 & $33,82^{\mathrm{A}}$ \\
\hline 4 & 33,9 & 34,1 & 30,9 & 29,9 & $32,26^{\mathrm{A}}$ \\
\hline 6 & 35,4 & 32,7 & 34,4 & 31,3 & $33,50^{\mathrm{A}}$ \\
\hline 8 & 32,8 & 34,8 & 35,3 & 32,2 & $33,80^{\mathrm{A}}$ \\
\hline 10 & 32,2 & 33,0 & 32,4 & 32,2 & $32,51^{\mathrm{A}}$ \\
\hline Parcelas ${ }^{4}$ & 33,8 & 33,5 & 31,6 & 29,9 & \\
\hline
\end{tabular}

${ }^{1}$ Porcentagem de inclusão de BIN em substituição ao BTPV.

${ }^{2}$ Horas após o fornecimento da ração pela manhã.

${ }^{3}$ Média das subparcelas (tempo).

${ }^{4}$ Média das parcelas (tratamentos).

${ }^{\mathrm{ABC}}$ Médias seguidas de letras iguais, na mesma coluna, não diferem entre si $(\mathrm{P}>0,05)$.

Os resultados demonstraram que a inclusão de BIN, e conseqüente redução de BTPV nas dietas experimentais, não prejudicou a produção de propionato. 


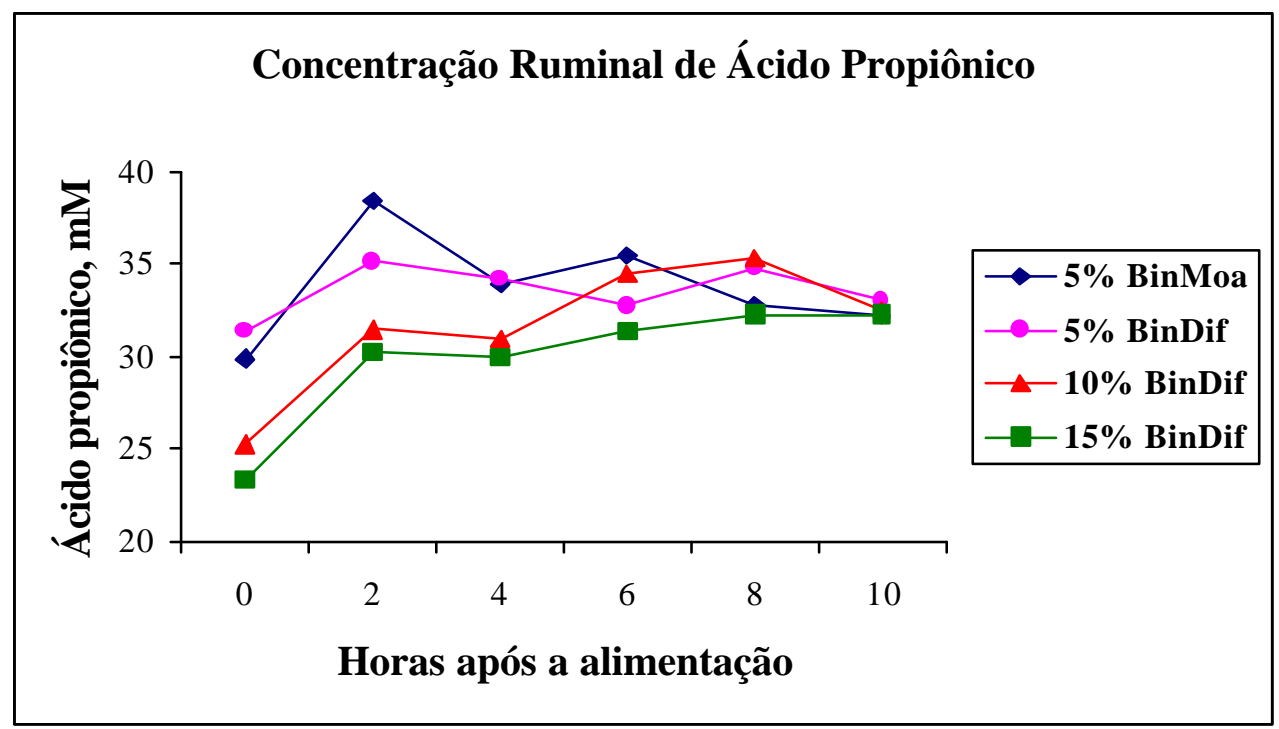

Figura 5- Efeito dos tratamentos sobre a concentração ruminal de ácido propiônico (mM).

\subsubsection{4 Ácido butírico}

O efeito dos tratamentos na concentração de butirato no fluido ruminal está representado na Tabela 19. Não houve diferença significativa $(P>0,05)$ na concentração de butirato entre os valores médios diários de cada tratamento (parcelas) nem na interação tratamento $\mathrm{x}$ tempo, no entanto houve diferença $(\mathrm{P}<0,05)$ no decorrer do dia (subparcelas). Hausknecht (1996) não encontrou diferença significativa $(\mathrm{P}>0,05)$ na produção de butirato em dietas contendo BTPV com ou sem fonte de fibra íntegra (8\% de cana-de-açúcar). No entanto, Castro (1989) encontrou maior produção de butirato em dietas com BTPV como volumoso exclusivo em comparação com o BIN. 
Tabela 19. Efeito dos tratamentos sobre a concentração de butirato no fluido ruminal $(\mathrm{mM} / \mathrm{L})$

\begin{tabular}{|c|c|c|c|c|c|}
\hline & & & atamentos & & \\
\hline & & $\%$ de in & são de BIN ${ }^{1}$ & & Subparcelas ${ }^{3}$ \\
\hline Tempos $^{2}$ & $5 \%$ BinMoa & 5\%BinDif & $10 \%$ BinDif & $15 \%$ BinDif & $\mathrm{P}<0,05$ \\
\hline 0 & 16,2 & 15,1 & 11,9 & 12,4 & $13,94^{\mathrm{B}}$ \\
\hline 2 & 19,5 & 17,3 & 16,0 & 14,8 & $16,92^{\mathrm{A}}$ \\
\hline 4 & 19,2 & 17,9 & 16,1 & 14,7 & $17,02^{\mathrm{A}}$ \\
\hline 6 & 20,3 & 16,3 & 17,3 & 15,7 & $17,45^{\mathrm{A}}$ \\
\hline 8 & 19,0 & 18,4 & 17,3 & 15,8 & $17,68^{\mathrm{A}}$ \\
\hline 10 & 18,2 & 17,4 & 15,9 & 15,6 & $16,81^{\mathrm{A}}$ \\
\hline Parcelas ${ }^{4}$ & 18,7 & 17,0 & 15,8 & 14,8 & \\
\hline
\end{tabular}

${ }^{\mathrm{T}}$ Porcentagem de inclusão de BIN em substituição ao BTPV.

${ }^{2}$ Horas após o fornecimento da ração pela manhã.

${ }^{3}$ Média das subparcelas (tempo).

${ }^{4}$ Média das parcelas (tratamentos).

${ }^{\mathrm{ABC}}$ Médias seguidas de letras iguais, na mesma coluna, não diferem entre si ( $\left.\mathrm{P}>0,05\right)$.

A Figura 6 ilustra o comportamento da concentração de butirato no fluido ruminal, que permaneceu num platô logo a partir de duas horas após a alimentação pela manhã.

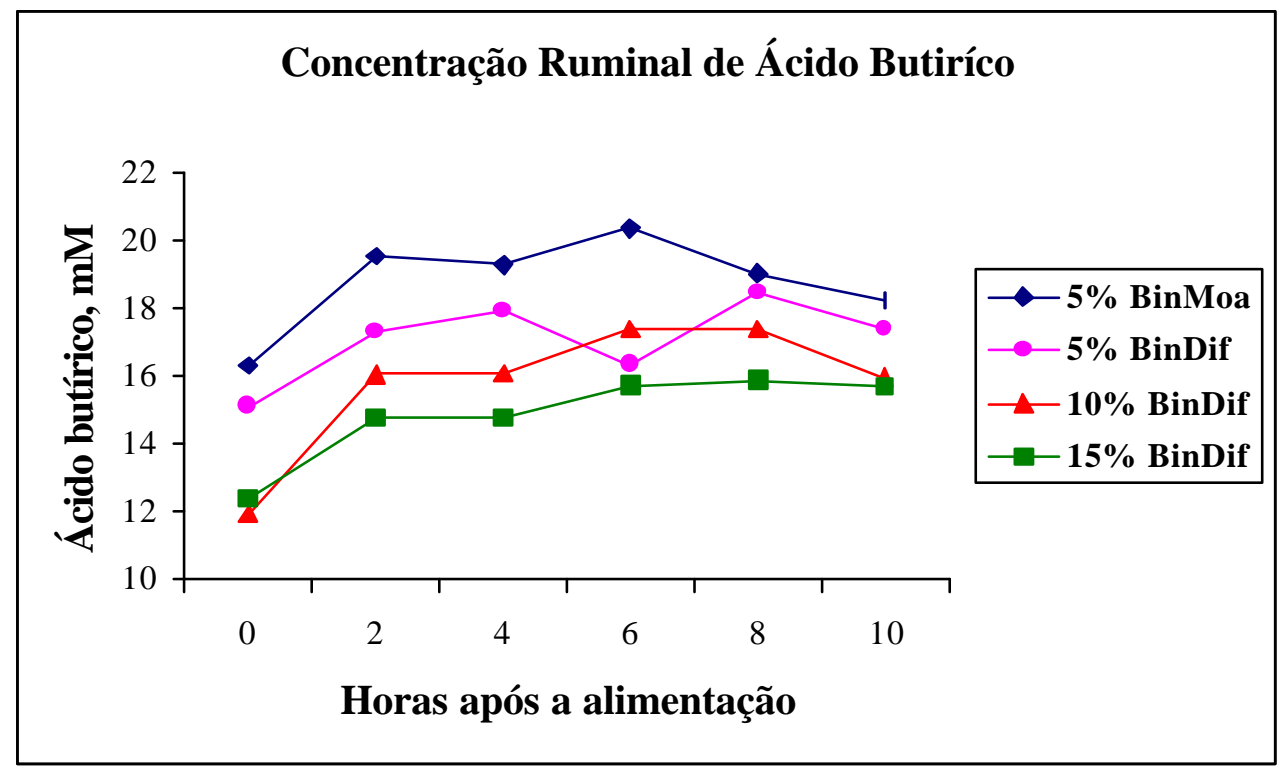

Figura 6- Efeito dos tratamentos sobre a concentração ruminal de ácido butírico (mM). 


\subsubsection{Relação acético/propiônico}

A relação acético/propiônico não apresentou diferença $(\mathrm{P}>0,05)$ entre os valores médios diários de cada tratamento (parcelas), porém houve diferença $(\mathrm{P}<0,05)$ na interação tempo x tratamento e ao longo do dia (subparcelas), demonstrado na Tabela 20. Hausknecht (1996) detectou diferenças na relação acético/propiônico quando da presença de fibra íntegra em dietas a base de BTPV, os resultados foram 3,08 e 2,75 para dietas com e sem fibra, respectivamente. Castro (1989) observou valores de 3,98 e 3,03 para dietas com BTPV e BIN como volumosos exclusivos, respectivamente.

A relação acetato/propionato atingiu seu valor máximo quatro horas após a alimentação, como pode ser observado na Figura 7. O tratamento com 15\% de BinDif apresentou diferenças $(\mathrm{P}<0,05)$ em relação ao tratamento com $5 \%$ de BinDif no tempo imediatamente anterior ao fornecimento das rações e duas horas após o trato matinal, provavelmente a redução do nível de BTPV nas dietas determinou um aumento da relação acetato/propionato em virtude dos aumentos nos teores de FDN e FDA das dietas.

Tabela 20. Efeito dos tratamentos sobre a relação acético/propiônico no fluido ruminal.

\begin{tabular}{lccccc}
\hline \multicolumn{5}{c}{ Tratamentos } \\
\hline Tempos $^{2}$ & $5 \%$ BinMoa & $5 \%$ BinDif & $10 \%$ BinDif & $15 \%$ BinDif & P<0,05 \\
\hline 0 & $2,85^{\mathrm{XY}}$ & $2,66^{\mathrm{Y}}$ & $2,87^{\mathrm{XY}}$ & $3,03^{\mathrm{X}}$ & $2,85^{\mathrm{A}}$ \\
2 & $2,80^{\mathrm{XY}}$ & $2,64^{\mathrm{Y}}$ & $2,97^{\mathrm{XY}}$ & $3,08^{\mathrm{X}}$ & $2,88^{\mathrm{A}}$ \\
4 & 2,88 & 2,73 & 2,99 & 3,01 & $2,91^{\mathrm{A}}$ \\
6 & 2,77 & 2,75 & 2,67 & 2,83 & $2,76^{\mathrm{B}}$ \\
8 & 2,80 & 2,66 & 2,77 & 2,83 & $2,77^{\mathrm{B}}$ \\
10 & 2,78 & 2,64 & 2,64 & 2,75 & $2,70^{\mathrm{B}}$ \\
Parcelas $^{4}$ & 2,82 & 2,68 & 2,82 & 2,92 & \\
\hline
\end{tabular}

\footnotetext{
${ }^{1}$ Porcentagem de inclusão de BIN em substituição ao BTPV.

${ }^{2}$ Horas após o fornecimento da ração pela manhã.

${ }^{3}$ Média das subparcelas (tempo).

${ }^{4}$ Média das parcelas (tratamentos).

${ }^{\mathrm{ABC}}$ Médias seguidas de letras iguais, na mesma coluna, não diferem entre si $(\mathrm{P}>0,05)$.

${ }^{\mathrm{XY}}$ Médias seguidas de letras iguais, na mesma linha, não diferem entre si $(\mathrm{P}>0,05)$.
} 


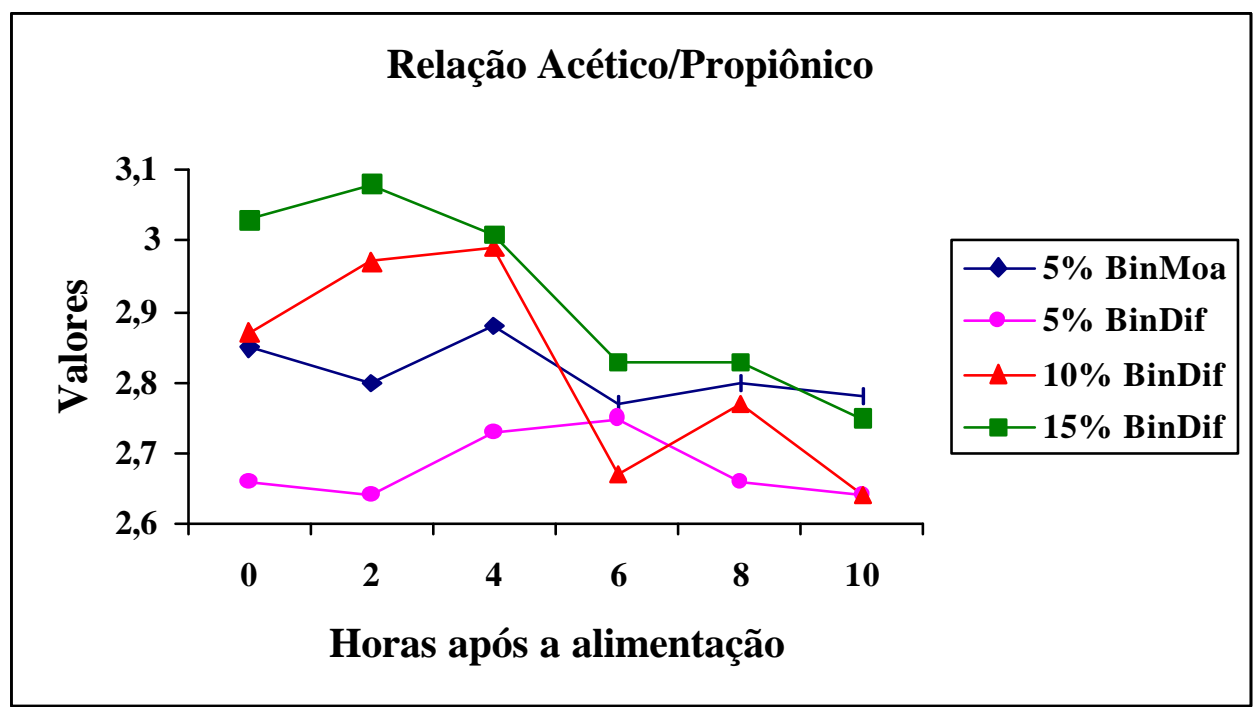

Figura 7- Efeito dos tratamentos sobre a relação acetato/propionato no fluido ruminal.

\subsection{Comportamento ingestivo}

Os resultados relativos ao número médio de minutos gastos pelos animais ingerindo, ruminando, mastigando e em ócio, expressos em minutos/dia, porcentagem $/ 24$ horas, minutos/kg de matéria seca e minutos/kg de FDN são demonstrados na Tabela 21.

A maior inclusão de BINdif determinou tendência $(\mathrm{P}<0,08)$ de aumento no tempo gasto para mastigação (minutos/dia e \% em $24 \mathrm{~h}$ ) e significância $(\mathrm{P}<0,05)$ para o tempo gasto com a mastigação em minutos/kg de FDN gerando progressiva redução no tempo de ócio $(\mathrm{P}=0,08)$.

Estes dados estão de acordo com Pereira et al. 1998, que encontraram maiores tempos gastos em ingestão e ruminação para dietas com alto teor de fibra em comparação com dietas de menor teor. Os autores também detectaram diferença no manejo alimentar adotado, observando maior ingestão pela manhã. 
Tabela 21. Efeitos dos tratamentos sobre o comportamento ingestivo.

\begin{tabular}{|c|c|c|c|c|c|c|}
\hline \multirow[b]{2}{*}{ Itens } & \multicolumn{4}{|c|}{ Tratamentos ${ }^{1}$} & \multirow[b]{2}{*}{$\mathrm{EPM}^{4}$} & \multirow[b]{2}{*}{ Teste $\mathrm{F}$} \\
\hline & $\begin{array}{c}5 \% \\
\text { BINmoa }^{2}\end{array}$ & $\begin{array}{c}5 \% \\
\text { BINdif }^{3}\end{array}$ & $\begin{array}{c}10 \% \\
\text { BINdif }\end{array}$ & $15 \%$ BINdif & & \\
\hline $\begin{array}{l}\text { ÓCIO } \\
\text { minutos/dia }\end{array}$ & 965 & 905 & 882 & 861 & 18,9 & 0,0828 \\
\hline$\%$ em $24 \mathrm{~h}$ & 67 & 62 & 61 & 59 & 1,3 & 0,0826 \\
\hline $\begin{array}{l}\text { INGESTÃO } \\
\text { minutos/dia }\end{array}$ & 157 & 187 & 191 & 190 & 10,8 & 0,3364 \\
\hline$\%$ em $24 \mathrm{~h}$ & 10 & 13 & 13 & 13 & 2,2 & 0,3355 \\
\hline Min/kg MS & $15^{\mathrm{A}}$ & $20^{\mathrm{AB}}$ & $20^{\mathrm{B}}$ & $23^{\mathrm{B}}$ & 1,2 & 0,0405 \\
\hline Min/kg FDN & 41 & 48 & 46 & 52 & 2,9 & 0,2243 \\
\hline $\begin{array}{l}\text { RUMINAÇÃO } \\
\text { minutos/dia }\end{array}$ & 289 & 302 & 323 & 361 & 21,4 & 0,2530 \\
\hline$\%$ em $24 \mathrm{~h}$ & 20 & 21 & 22 & 24 & 1,4 & 0,2528 \\
\hline Min/kg MS & $28^{\mathrm{A}}$ & $32^{\mathrm{A}}$ & $34^{\mathrm{A}}$ & $45^{\mathrm{B}}$ & 1,9 & 0,0117 \\
\hline Min/kg FDN & 74 & 78 & 78 & 99 & 5,5 & 0,0935 \\
\hline $\begin{array}{l}\text { MASTIGAÇÃO } \\
\text { minutos/dia }\end{array}$ & 447 & 490 & 515 & 551 & 17,4 & 0,0604 \\
\hline$\%$ em $24 \mathrm{~h}$ & 31 & 34 & 35 & 38 & 1,2 & 0,0602 \\
\hline Min/kg MS & $43^{\mathrm{A}}$ & $53^{\mathrm{B}}$ & $55^{\mathrm{B}}$ & $68^{\mathrm{C}}$ & 1,7 & 0,0013 \\
\hline Min/kg FDN & $115^{\mathrm{A}}$ & $127^{\mathrm{A}}$ & $125^{\mathrm{A}}$ & $151^{\mathrm{B}}$ & 4,9 & 0,0214 \\
\hline
\end{tabular}

\footnotetext{
${ }^{1}$ Efeito da substituição do BTPV pelo BIN.

${ }^{2}$ Bagaço in natura- moagem convencional; ${ }^{3}$ Bagaço in natura- difusão.

${ }^{4}$ Erro padrão da média.

${ }^{\mathrm{AB}}$ Médias seguidas da mesma letra na linha não diferem entre si a $5 \%$ de probabilidade.
}

Segundo Miranda et al. (1999), o tempo gasto com alimentação, ruminação e mastigação por unidade de consumo de MS e FDN é maior com a adição de fibra na dieta e que o aumento da atividade mastigatória pode proporcionar incremento da digestão ruminal e passagem. Os mesmos autores não encontraram diferenças no comportamento ingestivo de novilhas quando da utilização de diferentes fontes de nitrogênio não protéico e adição de probiótico em dietas contendo cana-de-açúcar. Já 
Welch (1982) cita que as fontes de fibra, além de estimular a ruminação, também têm outros efeitos como o aumento do tempo de retenção no rúmen.

O aumento dos níveis de BINdif bem como a substituição do BINdif por BINmoa, determinou redução na ingestão de MS das dietas $(\mathrm{P}<0,05)$. Esse fato poderia ser explicado pela maior demanda de tempo despendido para as atividades de ingestão e ruminação por unidade de MS ingerida, traduzidas por um maior tempo de mastigação/kg de MS (P<0,05). De acordo com Armentano \& Pereira (1997) o tempo gasto com a mastigação por kg de MS aumenta à medida que também se eleva o teor de FDN da fonte de fibra em virtude do maior tempo gasto com a atividade de mastigação e redução da ingestão de MS. Ao observarmos os valores de FDN das dietas com 10 e $15 \%$ de BINdif (44 e 45,4\%, respectivamente), e efetuando-se a comparação com a dieta basal de 5\% de BINdif (41,6\%), percebe-se um aumento de 4\% no valor de FDN tanto da dieta de $10 \%$ como da de $15 \%$ de BINdif, mesmo tendo-se níveis de substituição diferentes do BTPV pelo BINdif, em continuação percebe-se que os valores de tempo gasto com a mastigação por $\mathrm{kg}$ de MS aumentam linearmente a partir da dieta basal (5\% BINdif) até a dieta com 15\% de BINdif (490, 515 e 551 minutos, respectivamente), dessa forma, realizando-se cálculos a partir desses dados baseados em Armentano \& Pereira (1997), pode-se inferir que o BIN obtido por difusão é 2,4 vezes mais efetivo em estímulo a mastigação que o BTPV. 


\section{CONCLUSÕES}

Com a substituição do bagaço de cana-de-açúcar tratado sob pressão e vapor pelo bagaço in natura obtido pela moagem convencional ou processo de difusão, pode-se concluir:

- O consumo de MS, ganho de peso, conversão alimentar e peso vivo final não foram alterados pelos tratamentos, porém o consumo de MS parece ser prejudicado no maior nível de substituição.

- O nível de $15 \%$ de BIN obtido pelo processo de difusão obteve menor digestibilidade no trato digestivo total em $\mathrm{kg}$ da MS e MO, consumo de MS, MO, PB e FDN quando comparado com o BIN de moagem convencional.

- Os parâmetros ruminais $(\mathrm{pH}, \mathrm{AGV}$ totais, acetato, propionato, butirato, relação acetato/propionato e $\mathrm{N}-\mathrm{NH}_{3}$ também não diferiram entre os tratamentos.

- O comportamento ingestivo foi influenciado pela maior participação do BIN obtido por difusão, registrando-se maiores tempos despendidos para as atividades de ingestão, ruminação e mastigação em minutos/kg de MS e de FDN. A adoção do BIN obtido por moagem determinou maior consumo de MS, menor tempo despendido com as atividades de ingestão e ruminação e maior com a atividade de ócio.

- Baseado nos dados obtidos, o BIN advindo do processo de difusão pode ser utilizado como fonte de fibra íntegra até o nível de $10 \%$ sem prejudicar o desempenho dos animais. O BIN de moagem convencional teve comportamento semelhante em termos de desempenho, digestibilidade, parâmetros ruminais e diferenciado em relação ao comportamento ingestivo se comparado ao BIN advindo de difusão no mesmo nível de substituição. 


\section{REFERÊNCIAS BIBLIOGRÁFICAS}

ALLEN, M.S. Factors affecting carbohydrates utilization by dairy cattle. In: TRISTATE DAIRY NUTRITION CONFERENCE, Forty Wayne, 1994. Proceedings. Forty Wayne: Purdue University, 1994. p.107-124.

ALLEN, M.S. Fiber requirements for dairy cattle? How low can you go? In: CALIFORNIA NUTRITION CONFERENCE, Davis, 1996. Proceedings. Davis: University of California, 1996. p.12-18.

ALLEN, M.S. Relationship between fermentation and acid production in the rumen and requirement for physically effective fiber. Journal of Dairy Science, v.80, p.14471462, 1997.

ARMENTANO, L.E.; PEREIRA, M.N. Measuring the effectiveness of fiber by animal response trials. Journal of Dairy Science, v.80, p.1416-1425, 1997.

ASSOCIATION OFFICIAL ANALYTICAL CHEMISTS. Official methods of analysis.15. ed. Washington, 1990. 1298p.

BALSALOBRE, M.A.A.; FERNANDES, R.A.T.;SANTOS, P..M. Corte e transporte de cana-de-açúcar para consumo animal. In: SIMPÓSIO SOBRE NUTRIÇÃO DE BOVINOS, 7., Piracicaba, 1999. Anais. Piracicaba: FEALQ, 1999. p.7-26. 
BELTRAME FILHO, J.A. Eficiência energética e composição corporal de bovinos em crescimento. Piracicaba, 1998. 27p. Relatório (Graduação)- Escola Superior de Agricultura "Luiz de Queiroz", Universidade de São Paulo.

BERNDT, A. Composição corporal e exigências liquidas de energia e proteína de tourinhos Santa Gertrudis alimentados com dietas de alto teor de concentrado. Piracicaba, 2000. 73p. Dissertação (Mestrado)- Escola Superior de Agricultura "Luiz de Queiroz”, Universidade de São Paulo.

BULLE, M.L. M. Desempenho, composição corporal e exigências líquidas de energia e proteína de tourinhos de dois tipos genéticos alimentados com dietas de alto teor de concentrado. Piracicaba, 2000. 50p. Dissertação (Mestrado)- Escola Superior de Agricultura "Luiz de Queiroz", Universidade de São Paulo.

BURGI, R. Produção de bagaço de cana-de-açúcar auto hidrolisado e avaliação de seu valor nutritivo para ruminantes. Piracicaba, 1985. 61p. Dissertação (Mestrado) Escola Superior de Agricultura “Luiz de Queiroz”, Universidade de São Paulo.

BURGI, R. Rações convencionais para bovinos de corte em confinamento. In: SIMPÓSIO SOBRE PRODUÇÃO ANIMAL, 9., Piracicaba, 1996. Anais. Piracicaba: FEALQ, 1997. p.121-134.

CARVALHO, M.P.; BOIN, C.; LANNA, D.P.D. et al. Substituição parcial do milho por subprodutos energéticos em dietas de novilhos, com base em bagaço tratado à pressão e vapor: Digestibilidade, parâmetros ruminais e degradação in situ. Revista Brasileira de Zootecnia, v.27, n.6, p.1182-1192, 1998. 
CASTRO, F.B. Avaliação do processo de digestão do bagaço de cana-de-açúcar (Sacharum, sp. L) auto-hidrolisado em bovinos. Piracicaba, 1989. 122p. Dissertação (Mestrado) - Escola Superior de Agricultura "Luiz de Queiroz", Universidade de São Paulo.

CHANEY, A.L.; MARBACH, E.P. Modified reagents for determination of urea and ammonia. Clinical Chemistry, v.8, p.130, 1962.

CHURCH, D.C. The ruminant animal: digestive physiology and nutrition. Englewood Cliffs: Simon \& Schuster, 1988. 543p.

DELGADO, A.A. Tecnologia dos produtos agropecuários (Tecnologia do açúcar e das fermentações industriais). Piracicaba: ESALQ, 1975. 209p.

EASTRIDGE, L.M. Fibra para vacas leiteiras. In: SIMPÓSIO SOBRE PRODUÇÃO ANIMAL, 9., Piracicaba, 1996. Anais. Piracicaba: FEALQ, 1997. p.33-50.

EZEQUIEL, J.M.B.; ANDRADE, P. de. Avaliação de rações contendo bagaço de canade-açúcar e palha de arroz. Ingestão e Digestibilidade. Revista da Sociedade Brasileira de Zootecnia, v.17, n.5, p.446-455, 1988.

FAHEY, G.C.; BERGER, L.L. Carbohydrate Nutrition of Ruminants. In: CHURCH, D.C. The ruminant animal: digestive physiology and nutrition. Englewood Cliffs: Simon \& Schuster, 1988. cap. 14, p. 269-297.

FRANCISCO JÚNIOR, J.C. Efeito da uréia, do melaço e da lasalocida sódica sobre a fermentação ruminal de bovinos alimentados com bagaço de cana tratado com pressão de vapor. Piracicaba, 1994. 105p. Dissertação (Mestrado) - Escola Superior de Agricultura "Luiz de Queiroz”, Universidade de São Paulo. 
GOERING, H.K.; VAN SOEST, P.J. Forage fiber analysis (apparatus, reagents, procedures and some applications). Washington: USDA, 1970. 20p. (Agriculture Handbook, 379).

HAUSKNECHT, J.C. Efeito da fonte de fibra e do processamento físico do sorgo sobre o desempenho, digestibilidade e parâmetros ruminais de bovinos alimentados com rações a base de bagaço tratado sob pressão de vapor. Piracicaba, 1996. 86p. Dissertação (Mestrado) - Escola Superior de Agricultura "Luiz de Queiroz", Universidade de São Paulo.

HORTON, G.M.J.; PATE, F.M.; PITMAN, W.D. The effects of steam-pressure treatment, pelleting and ammoniation on the feeding value of sugarcane bagasse for cattle. Canadian Journal of Animal Science, v.71, p.79-86, 1991.

LANNA, D.P.D.; BOIN, C. Efeito de bicarbonato de sódio, feno e bagaço in natura sobre a digestibilidade e o desempenho de zebuínos em crescimento alimentados com bagaço de cana auto-hidrolisado. Anais Escola Superior de Agricultura “Luiz de Queiroz”, Piracicaba ,v.47, p.417-434, 1990.

LANNA, D.P.D.; MORAIS, J.P.; BOIN, C. et al. Desempenho e composição corporal de novilhas alimentadas com dois níveis de concentrado e bagaço de cana submetidos a diferentes processos de hidrolise. Revista Brasileira de Zootecnia, v.28, n.2, p.412-420, 1998.

LIMA, M.L.P.; ZANETTI, M.A. Utilização do bagaço hidrolisado como alimento volumoso para bovinos confinados. Revista da Sociedade Brasileira de Zootecnia, v.25, n.3, p.540-552, 1996. 
LOERCH, S.C. Dietas a base de concentrado para gado de corte. In: SIMPÓSIO SOBRE PRODUÇÃO ANIMAL, 9., Piracicaba, 1996. Anais. Piracicaba: FEALQ, 1997. p.135-160.

MAGALHÃES, L.R.G.; VASQUEZ, H.M.; SILVA, J.F.C. da. Bagaço hidrolisado e ponta de cana-de-açúcar (Sacharum officinarum), associados a duas fontes protéicas, na engorda de bovinos em confinamento. Revista Brasileira de Zootecnia, v.28, n.4, p.822-830, 1999.

MANZANO, R.P.; FUKUSHIMA, R.S.; GOMES, J.D.F. et al. Digestibilidade do bagaço de cana-de-açúcar tratado com reagentes químicos e pressão de vapor. Revista Brasileira de Zootecnia, v.29, n.4, p.1196-1204, 2000.

MATTOS, W.R.S. Utilização do bagaço de cana-de-açúcar na alimentação de ruminantes. In: CONGRESSO PAULISTA DE AGRONOMIA, 6., Piracicaba, 1987. Anais. Piracicaba: ESALQ, 1987. p.99-112.

MERCHEN, N.R. Digestion, absorption and excretion in ruminants. In: CHURCH, D.C. The ruminant animal: digestive physiology and nutrition. Englewood Cliffs: Simon \& Schuster, 1988. cap. 9, p. 172-201.

MERTENS, D.R. Analysis of fiber in feeds and its use in feed evaluation and ration formulation. In: SIMPÓSIO INTERNACIONAL DE RUMINANTES, Lavras, 1992. Anais. Lavras: SBZ, 1992. p. 1-32.

MERTENS,D.R. Formulating dairy rations: using fiber and carbohydrate analysis to formulate dairy rations. In: INFORMATION CONFERENCE WITH DAIRY AND FORAGE INDUSTRIES, Madison, 1996. Proceedings. Madison: U.S. Dairy Forage and Research Center, 1996. p.81-92. 
MERTENS, D.R. Creating a system for meeting the fiber requirements of dairy cows. Journal of Dairy Science, v.80, p.1463-1481, 1997.

MERTENS, D.R. NDF: Fiber composition and value of forages with different NDF concentrations. In: SOUTHWEST NUTRITION AND MANAGEMENT CONFERENCE, Arizona, 1998. Proceedings. Arizona: University of Arizona, 1998. p.85-99.

MERTENS, D.R. NDF: Fiber composition and value of forages with different NDF concentrations. In: SOUTHWEST NUTRITION AND MANAGEMENT CONFERENCE, Arizona, 1999. Proceedings. Arizona: University of Arizona, 1999. p.91-111.

MIRANDA, L.F.; QUEIROZ, A.C.; VALADARES FILHO, S.C. et al. Comportamento ingestivo de novilhas leiteiras alimentadas com dietas à base de cana-de-açúcar. Revista Brasileira de Zootecnia, v.28, n.3, p. 614-620, 1999.

NATIONAL RESEARCH COUNCIL. Nutrient requirements of dairy cattle. 6. ed. Washington : National Academic Press, 1989. 158p.

NUSSIO, L.G.; BALSALOBRE, M.A. Utilização de resíduos fibrosos da industrialização da cana-de-açúcar na alimentação de bovinos. In: SIMPÓSIO SOBRE NUTRIÇÃO DE BOVINOS, 5., Piracicaba, 1993. Anais. Piracicaba: FEALQ, 1993. p. 127-150.

NUSSIO, L.G.; LIMA, M.L.M.; MATTOS, W.R.S. Caracterização e importância da fibra na alimentação de ruminantes (compact disc). In: SIMPÓSIO INTERNACIONAL SOBRE PRODUÇÃO DE BOVINOS LEITEIROS. Carambeí, 2000. Simpósios: trabalhos. Carambeí: Fundação ABC, 2000. 
OWENS, F.N.; GOETSCH, A.L. Ruminal fermentation. In: CHURCH, D.C. The ruminant animal: digestive physiology and nutrition. Englewood Cliffs: Simon \& Schuster, 1988. cap. 8, p. 145-171.

PALMQUIST, V.T.; CONRAD, H. Origin of plasma fatty acids in lactating cows fed high fat diets. Journal of Dairy Science, v.54, p. 1025, 1971.

PATE, F.M. Value of treating bagasse with steam under pressure for cattle feed. Tropical Agriculture, v.59, n.4, p.293-297, 1982.

PEREIRA, E.S.; QUEIROZ, A.C.; NEVES, J.S. et al. Níveis de fibra em dietas de novilhas leiteiras. 2. Comportamento ingestivo. In: REUNIÃO ANUAL DA SOCIEDADE BRASILEIRA DE ZOOTECNIA, Botucatu, 1998. Anais. Botucatu: SBZ, 1998. p. 524-526.

PRESTON, R.L. Management of high concentrate diets in feedlot. In: CONGRESSO BRASILEIRO DE NUTRIÇÃO ANIMAL, Campinas, 1998. Anais. Campinas: CBNA, 1998. p.82-91.

QUEIROZ, A.C. de; SANCHEZ, N.R.; RESENDE, F.D. et al. Tamanho médio de partícula, módulos de finura e de uniformidade da digesta ao longo do trato gastrintestinal de ruminantes de diferentes grupos genéticos. Revista da Sociedade Brasileira de Zootecnia, v.25, n.1, p.125-141, 1996.

RIBEIRO, C.V.M. Efeito da substituição do grão de milho pelo de milheto (Pennisetum americanum) na dieta de vacas em lactação. Piracicaba, 1999, 67p. Dissertação (Mestrado)- Escola Superior de Agricultura "Luiz de Queiroz", Universidade de São Paulo. 
SANTOS, F.A.P. Efeito de bicarbonato de sódio, lasalocida e cana-de-açúcar sobre o desempenho de bovinos alimentados com bagaço de cana tratado sob pressão de vapor. Piracicaba, 1991. 127p. Dissertação (Mestrado) - Escola Superior de Agricultura "Luiz de Queiroz”, Universidade de São Paulo.

SAS INSTITUTE. SAS/STAT: user's guide. Cary, 1997. 1028p.

SILVA, D.J. da. Análise de alimentos (métodos químicos e biológicos). Viçosa: UFV, 1981. 166p.

SILVA, S.C. da. Efeito de bicarbonato de sódio e/ou lasalocida sobre os parâmetros ruminais de bovinos alimentados com bagaço de cana tratado à pressão de vapor. Piracicaba, 1990. 130p. Dissertação (Mestrado) - Escola Superior de Agricultura "Luiz de Queiroz”, Universidade de São Paulo.

SIMAS, J.M. Processamento de grãos para rações de vacas leiteiras. In: SIMPÓSIO SOBRE PRODUÇÃO ANIMAL, 9., Piracicaba, 1996. Anais. Piracicaba: FEALQ, 1997. p.7-32.

THIAGO, L.R.L.S.; GILL, M. Consumo voluntário : fatores relacionados com a degradação e passagem da forragem pelo rúmen. Campo Grande: EMBRAPA, 1990. 65p. (CNPGC. Documentos, 43)

THIAGO, L.R.L.S.; SILVA, J.M.; COSTA, F.P. et al. Engorda de novilhos em confinamento utilizando subprodutos de microdestilarias de álcool. In: REUNIÃO ANUAL DA SOCIEDADE BRASILEIRA DE ZOOTECNIA, Pelotas, 1983. Anais. Pelotas: SBZ, 1983. p.100.

VAN SOEST, P.J. Nutritional ecology of the ruminant. Ithaca: Cornell University Press, 1994. 476p. 
VAN SOEST, P.J.; WINE, R.H. The use of detergents in analysis of fibrous feeds: IV. Determination of plant cell-wall constituents. Journal Association Of Official Analytical Chemists. v.50, p.50, 1967.

VAN SOEST, P.J.; ROBERTSON, J. B.; LEWIS, B.A. Methods for dietary fiber, neutral detergent fiber and nonstarch polysaccharides in ration to animal nutrition. Journal of Dairy Science. v.74, p.3583-3597, 1991.

WELCH, J.G. Rumination, particle size and passage from the rumen. Journal of Animal Science, v.54, n.4, p.885-894, 1982. 